\title{
Impact of Isahaya dike construction on DO concentration in the Ariake Sea
}

\author{
Soichi Yamaguchi ${ }^{1}\left[\right.$ ? Yuichi Hayami $^{2}$
}

Received: 8 May 2017 / Revised: 15 November 2017 / Accepted: 16 November 2017 / Published online: 4 January 2018

(c) The Author(s) 2017. This article is an open access publication

\begin{abstract}
In the Ariake Sea, dike construction in Isahaya Bay in 1997 for reclamation and disaster prevention was thought to cause big anthropogenic impacts on the marine ecosystem. Currently, hypoxia or anoxia occurs every summer in Isahaya Bay and the inner Ariake Sea. However, the effects of the dike construction on the DO concentration are unclarified. The present study evaluated the impact of the dike construction on the DO concentration by applying a numerical ecosystem model. The present calculation showed that the dike construction could affect the DO concentration in summer in a wider area than reported before in the steady state with a neap-spring tidal cycle. In Isahaya Bay, the dike construction caused a decrease of DO concentration greater than $2.0 \mathrm{mg} \mathrm{l}^{-1}$, due to the decrease in DO supply from the vertical diffusion process with reduction of tidal current and the intensification of the density stratification. The dike construction also affected the DO concentration in the inner Ariake Sea by decreasing the DO concentration of the water transported by the estuarine circulation and the reduction of the diffusive supply of oxygen vertically with stratification enhanced by the dike construction. For the first time, this study showed with numerical simulation that the dike construction could affect the DO concentration in a wide area of the Ariake Sea.
\end{abstract}

Keywords Hypoxia $\cdot$ Ariake Sea $\cdot$ Anthropogenic impact $\cdot$ FVCOM $\cdot$ Ecosystem model $\cdot$ Neap spring cycle $\cdot$ Estuarine circulation $\cdot$ Isahaya reclamation

\section{Introduction}

Dissolved oxygen (DO) is vital for most marine organisms. Hypoxia is a condition that occurs when the DO concentration falls below the level necessary to sustain most animal life (Rabalais and Turner 2001). Currently, anthropogenic hypoxia occurs in semi-enclosed waters around the world (e.g., Chesapeake Bay, Officer et al. 1984; Long Island Sound, Welsh and Eller 1991; Baltic Sea-Kattegat transition, Jørgensen 1996). In Japan, bottom hypoxia in semi-enclosed bays has been recognized as an important environmental

Soichi Yamaguchi

yamaguti@esst.kyushu-u.ac.jp

1 Department of Earth System Science and Technology, Kyushu University, Kasugakoen 6-1, Kasuga, Fukuoka 816-8580, Japan

2 Institute of Lowland and Marine Research, Saga University, 1 Honjo-machi, Saga, Saga 840-8502, Japan problem since the 1970s (e.g., Mikawa Bay, Suzuki and Matsukawa 1987; Ise Bay, Kuno 1996; Tokyo Bay, Kobayashi 1994; Osaka Bay, Joh 1989, etc). The depletion of DO affects benthic functionality as well as the structure of the benthic community (e.g. Suzuki 2001). It can also adversely affect fishery resources, especially bivalves (Suzuki 2001).

The Ariake Sea (Fig. 1) is an estuary or gulf-type region of freshwater influence (ROFI) on Kyushu Island, western Japan. It is approximately $100 \mathrm{~km}$ long and, on average, $18 \mathrm{~km}$ wide and $20 \mathrm{~m}$ deep. It has significant features, e.g. a large tidal range up to $6 \mathrm{~m}$ at spring tide, and extensive mudflats that account for approximately $40 \%$ of total tidal flat areas in Japan. The Ariake Sea has experienced anthropogenic impacts, leading to severe hypoxia every summer in the inner Ariake Sea (northern sea area of the black dashed line in Fig. 1b) and Isahaya Bay, a small tributary bay of the western Ariake Sea, as well as damage to fisheries (Ministry of the Environment 2006; Yoshino et al. 2010).

The Ministry of Agriculture, Forestry and Fisheries of Japan constructed a dike in Isahaya Bay in 1997 to reclaim 
(a)
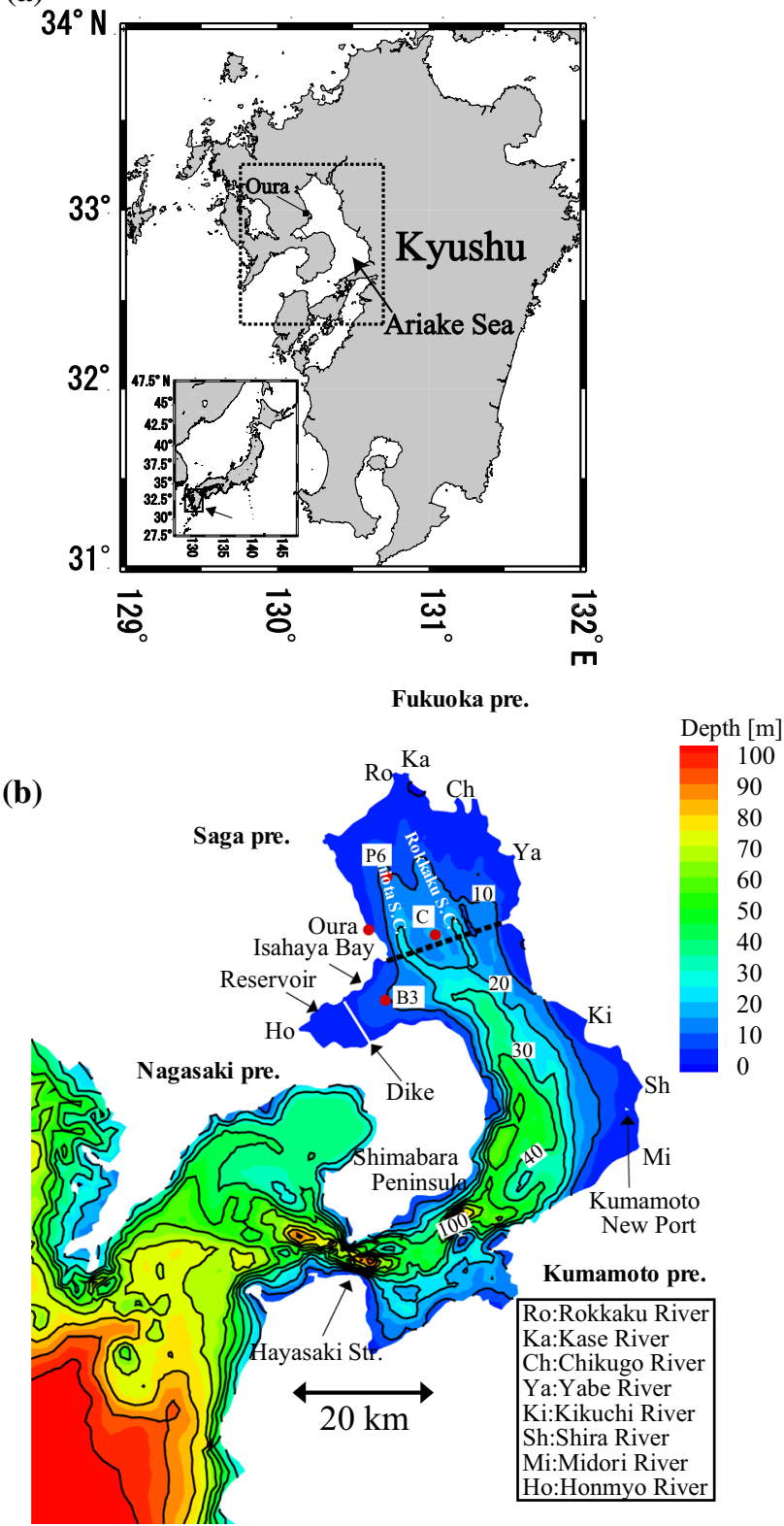

Fig. 1 Location map (a) and bottom geometry (b) of the Ariake Sea

land for agriculture and disaster prevention (Fig. 1b). The dike, $7 \mathrm{~km}$ long, separated the bay into two areas. Reclaimed land with an area of $8.2 \mathrm{~km}^{2}$ and a fresh water reservoir with an area of $26 \mathrm{~km}^{2}$ and a mean depth of $1.1 \mathrm{~m}$ were constructed inside the dike. A certain volume of the reservoir fresh water is sometimes discharged from two gates installed in the south and north of the dike. The dike construction reduced the tidal current in Isahaya Bay and in the middle of the Ariake Sea (e.g. Unoki 2002; Tai and Yano 2008). Nagao et al. (2010) evaluated the effect of geographical modifications between 1990 and 2001 on the DO field in Isahaya Bay and the inner Ariake Sea using numerical simulation. The main geographical modifications during this period were construction of the Isahaya dike and the Kumamoto new port (Fig. 1b). They reported that the water volume with DO concentration below $2.0 \mathrm{mg} \mathrm{l}^{-1}$ increased by approximately $38 \%$ in Isahaya Bay and decreased by $11 \%$ in the inner area of the Ariake Sea. To the best of our knowledge, this is the only report that suggests the effects of the dike construction on the DO concentration using numerical simulation. However, the mechanism and degree of the DO concentration change is still unclear. Yamaguchi et al. (2015) accurately reproduced short-term DO variability in the Ariake Sea using an ecosystem model. Since almost no data exist on the DO concentration in Isahaya Bay before the dike construction, this tool is very useful for evaluating DO changes due to the dike construction.

The objective of this study is to reveal the DO change due to the dike construction and to clarify the mechanism behind it. This study, as a first step, evaluated the DO change under seasonally averaged conditions during the summer stratified season, the fundamental case study for estimating the impact of the dike construction on DO concentration. For this, we applied an ecosystem model that can reproduce the DO concentration with high accuracy, and investigated the difference in DO concentration with and without the dike construction. The outline of this paper is as follows: Sect. 2 provides details of the numerical model; in Sect. 3, results are described; Sect. 4 discusses the impact of the dike construction on DO concentrations; and Sect. 5 presents our conclusions.

\section{Methods}

This study performed numerical simulations using a finite volume community ocean model (FVCOM; Chen et al. 2003) to reproduce the abiotic/biotic environment with/without the presence of the dike. The numerical domain and horizontal/vertical coordinate system are shown in Fig. 2. The horizontal domain consisted of an unstructured triangular grid. The grid size was about $500 \mathrm{~m}$ at the head of the Ariake Sea, gradually increasing to $5000 \mathrm{~m}$ at the open boundary. Inserted figures in Fig. 2 show the horizontal grids around Isahaya Bay with/without the dike construction. The vertical coordinate system was a combination of a $z$-coordinate system for the surface layer (1-m grid size from 0 to $5-\mathrm{m}$ depth) and a general $\sigma$-coordinate system for layers deeper than $5.0 \mathrm{~m}$ (Pietrzak et al. 2002). The horizontal pressure gradient force was evaluated using the scheme developed by Ciappa (2006) for reducing errors in the force. The total number of vertical $\sigma$ layers was 13 .

The model is composed of two models: a hydrographic model and an ecosystem model. The hydrographic model is calculated independently from the ecosystem model, 


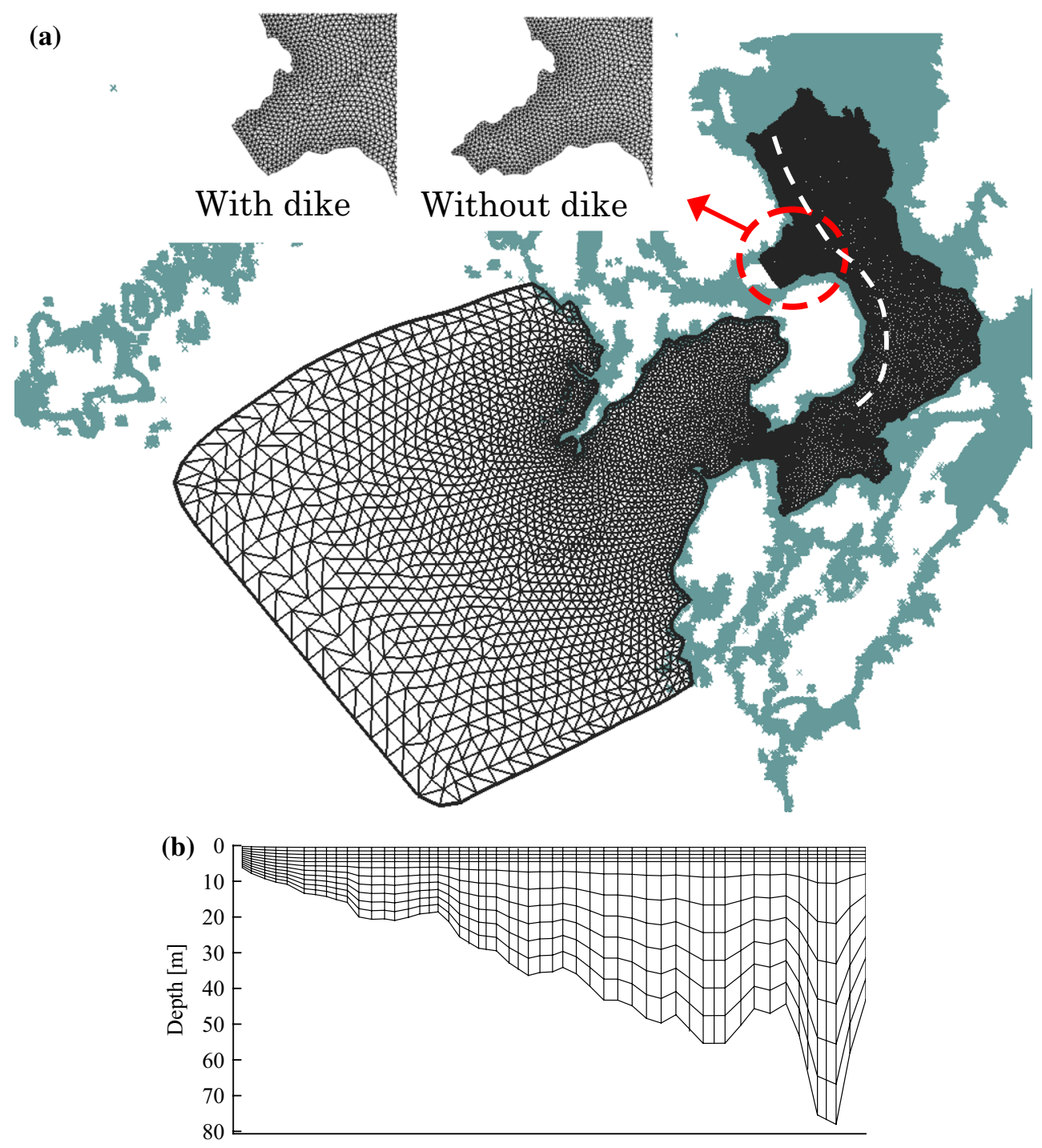

Fig. 2 Calculation domain, unstructured triangular grid (a) and vertical coordinate system (b) along the dashed line in a

whereas the ecosystem model receives inputs about the flow, turbulence, temperature and salinity field calculated by the hydrographic model. The objective of numerical simulation in this study was to estimate the impact of the dike construction on DO concentration under the seasonally averaged abiotic/biotic environment as described in the previous section. For that, the following numerical settings were applied.

\subsection{Physical environments}

The hydrographic model simulates the three-dimensional physical field in the Ariake Sea and demonstrates the variability of flow field, salt and heat transport. The model includes tidal forcing, surface wind and a local density gradient with realistic coastal topography and bathymetry and wet-dry treatment methods in tidal flat areas. Under hydrostatic and Boussinesq approximations on a rotating Cartesian coordinate system, the model employs equations of fluid motion, flow continuity and conservation of heat and salt to determine the local distribution of model variables. The vertical mixing process is parameterized with a turbulence model by the updated Mellor-Yamada 2.5 turbulent closure scheme (Mellor and Yamada 1982; Galperin et al. 1988). Details on the hydrographic model can be found in the work of Chen et al. (2003). In addition, the present model incorporated suspended sediment dynamics (Hamada et al. 2009) to reproduce the sunlight profile in the water column of the Ariake Sea.

The simulation initially began with water being at rest and temperature and salinity field averaged during the stratified season (June to August) from 1995 to 2005. The temperature/salinity data in the Ariake Sea (inside Hayasaki Str. in 
Fig. 1) were based on monthly monitoring data supplied by Fukuoka, Saga and Kumamoto prefectural fishery offices, and those outside Hayasaki Str. were from FRA-JCOPE2 reanalysis data (Miyazawa et al. 2009). Heat and fresh water flux at the sea surface were calculated by the COARE algorithm (Fairall et al. 2003) using weather data (air temperature, air pressure, humidity, solar radiation, rain fall, cloud cover and vapor pressure) observed in Saga prefecture by the Japan Meteorological Agency (Fig. 1). For wind condition, we used the meso-scale model (MSM) dataset supplied by the Japan Meteorological Agency. The MSM provides the horizontal 5-km-grid wind field $10 \mathrm{~m}$ above the land/ sea surface around Japan. For open boundary conditions, six tidal components (M2, S2, N2, K1, O1 and P1) were forced using the results of NAO.99Jb regional tide model (Matsumoto et al. 2000) to reproduce neap-spring tidal variation. Temperature and salinity at the open boundary were specified using FRA-JCOPE2 reanalysis data (Miyazawa et al. 2009). To smoothly incorporate FRA-JCOPE2 variables into FVCOM ones at the open boundary, a relaxation scheme (Davies 1976) was applied to the conservation equations of temperature and salinity within a range of $10 \mathrm{~km}$ from the open boundary. The model considered eight rivers (Chikugo, Kase, Rokkaku, Yabe, Kikuchi, Shira, Midori and and Honmyo in Fig. 1). River water volumes were monitored upstream of the river mouth by the Ministry of Land, Infrastructure, Transport and Tourism. As a result, the river water volume was modified using the ratio of watershed area at the river mouth to that at the measurement station. The reservoir made by the dike construction is connected to the sea through the north and south gates of the dike in Isahaya Bay. Fresh water discharges into Isahaya Bay through the two gates. Simulation with dike construction considered fresh water discharge from the two gates of the dike, instead of discharge from the Honmyo River, in the same manner as for river inflows (Chen et al. 2003). The volume of fresh water through the gates has been measured by the Ministry of Agriculture, Forestry and Fisheries of Japan. In this study, the freshwater discharge, set as the seasonally averaged discharge from June to August, was kept constant. The strength of density stratification was evaluated using the following equation (Simpson et al. 1990),

$\phi=\frac{1}{D} \int_{-H}^{\eta} g z\left(\rho_{\text {ave }}-\rho\right) \mathrm{d} z$

where $D$ is the total depth of the water column $(=\eta+\mathrm{H}), \eta$ is the fluctuation of water level, $H$ is the water depth under the mean sea level, $g$ is the gravitational acceleration, $z$ is the depth, $\rho$ is the density of sea water and $\rho_{\text {ave }}$ is the vertically averaged density of sea water. $\phi$ is the energy $\left(\mathrm{J} \mathrm{m}^{-3}\right)$ required to vertically mix the water column. A large value of $\phi$ indicates development of density stratification. The residual current was obtained using a 48-h tide-killer filter (Hanawa and Mitsudera 1985).

\subsection{Ecological environments}

The ecosystem model applied in this study is shown in Fig. 3a. The DO fluxes are presented in Fig. 3b. Definitions of model variables and arrows are shown in Tables 1 and 2 , respectively. The variables of the ecosystem model are phytoplankton, zooplankton, dissolved organic matter, particulate organic matter, dissolved inorganic nitrogen (ammonium, nitrate and nitrite), dissolved inorganic phosphorus, phytoplankton and particulate organic matter deposited on the seabed (PHY_B, POC_B, respectively), oyster reef (OYSTER) and DO concentration. The model describes the major material fluxes among these model variables through physical and biochemical processes in terms of oxygen $(\mathrm{O})$, carbon $(\mathrm{C})$, nitrogen $(\mathrm{N})$ and phosphorus $(\mathrm{P})$ cycling. The dynamics of each variable $[B]$, except for PHY_B, POC_B
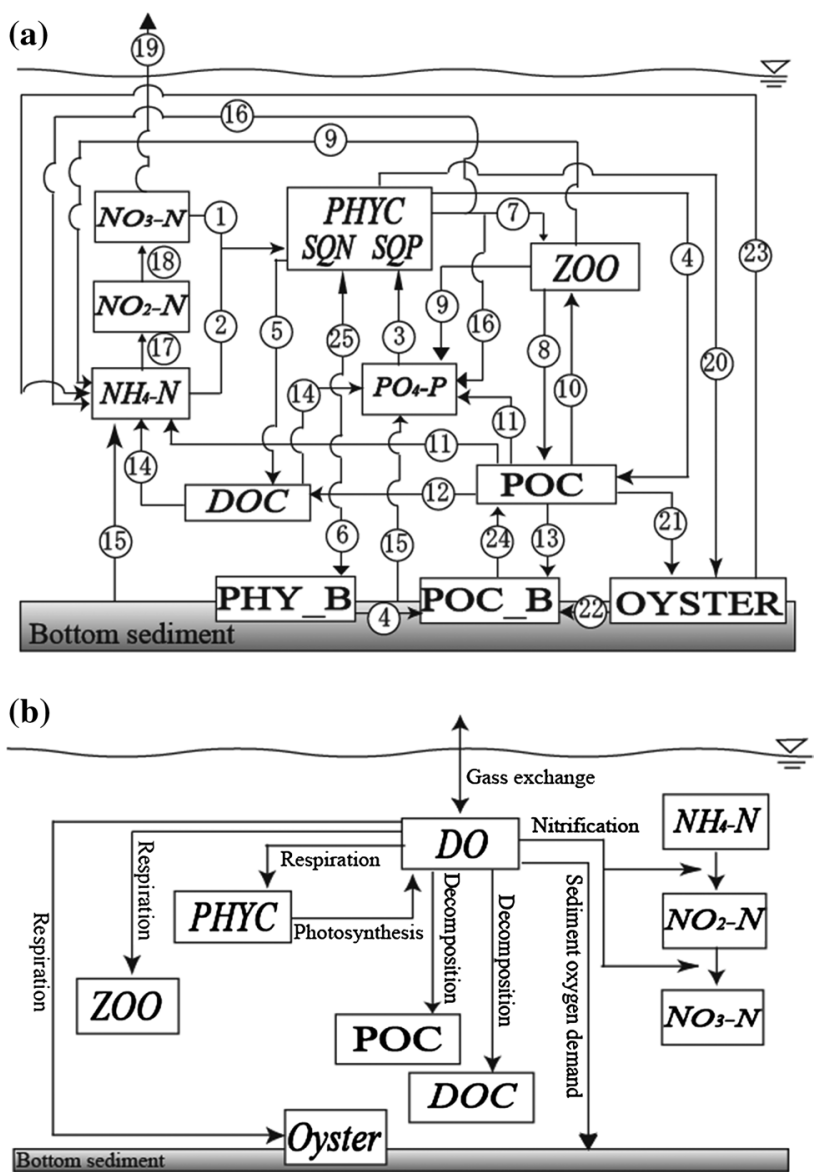

Fig. 3 Ecosystem model used in the present study (a) and DO flux (b). Definition of components and arrows are listed in Tables 1 and 2, respectively 
and OYSTER, were calculated using the following advection-diffusion equation that includes a biochemical variation process:

$$
\begin{aligned}
\frac{\partial B}{\partial t} & +u \frac{\partial B}{\partial x}+v \frac{\partial B}{\partial y}+w \frac{\partial B}{\partial z} \\
& =K_{\mathrm{h}}\left(\frac{\partial^{2} B}{\partial x^{2}}+\frac{\partial^{2} B}{\partial y^{2}}\right)+\frac{\partial}{\partial z}\left(K_{z} \frac{\partial B}{\partial z}\right)+\frac{\partial B^{*}}{\partial t}
\end{aligned}
$$

where $u, v$ and $w$ are the east-west, south-north and vertical components of velocity, respectively, $K_{\mathrm{h}}$ is the horizontal diffusion coefficient calculated by Smagorinsky (1963) and $K_{\mathrm{z}}$ is the vertical diffusion coefficient calculated by the modified version of the Mellor-Yamada 2.5 turbulent closure scheme (Mellor and Yamada 1982; Galperin et al. 1988). The last term on the right-hand side of the equation is a biochemical variation process calculated by the ecosystem model. The equations satisfy the mass conservation of $\mathrm{O}$, $\mathrm{C}, \mathrm{N}$ and $\mathrm{P}$, and are comprised of transport/turbulent diffusion terms due to the physical processes and production/consumption terms due to the biochemical processes. Each path of the $\mathrm{O}-\mathrm{C}-\mathrm{N}-\mathrm{P}-$ coupled cycle in a pelagic system caused by biochemical processes is derived from empirical/experimental formulation basically based on the Nakata model (Nakata et al. 1993). Those related to the oyster reef including its biomass distribution in the Ariake Sea are based on reports by Seikai National Fisheries Research Institute and Saga University $(2012,2013)$. The values of the biochemical processes are calculated at each time step. Changes in the biochemical processes affect the dynamics/spatial distribution of the model variables and vice versa.

The DO-consuming/producing biochemical processes are described with the following equation;

Table 1 Definition of variables of the ecosystem model used in the

\begin{tabular}{|c|c|c|c|c|}
\hline Variables & Definition & Unit & 11 & $\mathrm{NH}_{4}-\mathrm{N}$ or $\mathrm{PO}_{4}-\mathrm{P}$ release by decomposition of $\mathrm{POC}$ \\
\hline PHYC & Phytoplankton in carbon units & $\mathrm{mgC} \mathrm{m}^{-3}$ & & DOC creation by decomposition surplus of POC \\
\hline SQN & Cell quota of phytoplankton nitrogen & $\mathrm{mgN} \mathrm{m}^{-3}$ & 13 & Sinking of POC \\
\hline$S \cap P$ & & & 14 & $\mathrm{NH}_{4}-\mathrm{N}$ or $\mathrm{PO}_{4}-\mathrm{P}$ release by decomposition of $\mathrm{DOC}$ \\
\hline SQP & Cell quota of phytoplankton phosphorus & $\mathrm{mgP} \mathrm{m}^{-3}$ & 15 & Release of nutrients from the seabed \\
\hline $\mathrm{ZOO}$ & Zooplankton & $\mathrm{mgC} \mathrm{m}{ }^{-3}$ & 16 & Release of cell quota of phytoplankton by grazing \\
\hline POC & Particulate organic matter in carbon units & $\mathrm{mgC} \mathrm{m}^{-3}$ & & of zooplankton \\
\hline DOC & Dissolved organic matter in carbon units & $\mathrm{mgC} \mathrm{m} \mathrm{m}^{-3}$ & 17 & Nitrification of $\mathrm{NH}_{4}-\mathrm{N}$ \\
\hline $\mathrm{NO}_{3}-\mathrm{N}$ & Nitrate & $\mu \mathrm{M}$ & 18 & Nitrification of $\mathrm{NO}_{2}-\mathrm{N}$ \\
\hline $\mathrm{NO}_{2}-\mathrm{N}$ & Nitrite & $\mu \mathrm{M}$ & 19 & Denitrification \\
\hline $\mathrm{NH}_{4}-\mathrm{N}$ & Ammonium & $\mu \mathrm{M}$ & 20 & Grazing of phytoplankton by oyster \\
\hline $\mathrm{PO}_{4}-\mathrm{N}$ & Phosphate & $\mu \mathrm{M}$ & 21 & Grazing of POC by oyster \\
\hline DO & Dissolved oxygen & $\operatorname{mg~} 1^{-1}$ & 22 & Feces of oyster \\
\hline OYSTER & Oyster reef & $\mathrm{gC} \mathrm{m}^{-2}$ & 23 & Excretion of oyster \\
\hline PHY_B & PHYC deposited on the seabed & $\mathrm{mgC} \mathrm{m}^{-2}$ & 24 & Resuspension of POC from the seabed \\
\hline POC_B & POC deposited on the seabed & $\mathrm{mgC} \mathrm{m}{ }^{-2}$ & 25 & Resuspension of phytoplankton from the seabed \\
\hline
\end{tabular}
present study $\left(\frac{\partial \mathrm{DO}}{\partial t}\right)=D_{1}-D_{2}-D_{3}-D_{4}-D_{5}-D_{6}-D_{7}-D_{8}+D_{9}-D_{10}$

$D_{1}$ is DO production by photosynthesis of phytoplankton, $D_{2}, D_{3}$ and $D_{10}$ are consumption by respiration of phytoplankton, zooplankton and oyster, respectively. $D_{4}$ and $D_{5}$ are DO consumption by decomposition of particulate and dissolved organic matter, respectively. $D_{6}$ and $D_{7}$ are consumption by nitrification of $\mathrm{NH}_{4}-\mathrm{N}_{\text {and }} \mathrm{NO}_{2}-\mathrm{N}$, respectively, and $D_{8}$ by consumption of the seabed sediments. $D_{9}$ is DO exchange through the sea surface due to the reaeration. Resuspension of the bottom sediment with high organic matter due to strong tidal current increases the DO consumption in the Ariake Sea (Tokunaga et al. 2009). To take the increase of DO consumption due to the bottom organic matter resuspension into account, the amount of phytoplankton and POC deposited on the seabed are calculated as independent variables (PHY_B and POC_B in Fig. 3a) and resuspended/returned to PHYC and POC in the water column (the lowest $\sigma$ layer) in proportion to the amount of the sediment resuspension calculated by the suspended

Table 2 Description of each component flux taken into consideration

\begin{tabular}{|c|c|}
\hline No. & Definition \\
\hline 1 & Uptake of nitrate by phytoplankton \\
\hline 2 & Uptake of ammonia nitrogen by phytoplankton \\
\hline 3 & Uptake of phosphate by phytoplankton \\
\hline 4 & Natural mortality of phytoplankton \\
\hline 5 & Extracellular release of DOC by phytoplankton \\
\hline 6 & Sinking of phytoplankton \\
\hline 7 & Grazing of phytoplankton by zooplankton \\
\hline 8 & Natural mortality of zooplankton \\
\hline 9 & Excretion of zooplankton \\
\hline 10 & Grazing of POC by zooplankton \\
\hline 11 & $\mathrm{NH}_{4}-\mathrm{N}$ or $\mathrm{PO}_{4}-\mathrm{P}$ release by decomposition of $\mathrm{POC}$ \\
\hline 12 & DOC creation by decomposition surplus of POC \\
\hline 13 & Sinking of POC \\
\hline 14 & $\mathrm{NH}_{4}-\mathrm{N}$ or $\mathrm{PO}_{4}-\mathrm{P}$ release by decomposition of DOC \\
\hline 15 & Release of nutrients from the seabed \\
\hline 16 & $\begin{array}{l}\text { Release of cell quota of phytoplankton by grazing } \\
\text { of zooplankton }\end{array}$ \\
\hline 17 & Nitrification of $\mathrm{NH}_{4}-\mathrm{N}$ \\
\hline 18 & Nitrification of $\mathrm{NO}_{2}-\mathrm{N}$ \\
\hline 19 & Denitrification \\
\hline 20 & Grazing of phytoplankton by oyster \\
\hline 21 & Grazing of POC by oyster \\
\hline 22 & Feces of oyster \\
\hline 23 & Excretion of oyster \\
\hline 24 & Resuspension of POC from the seabed \\
\hline 25 & Resuspension of phytoplankton from the seabed \\
\hline
\end{tabular}
in the present ecosystem model 
sediment model (Hamada et al. 2009). As a result, the accuracy of DO concentration reproduction by the model was greatly improved. Details of the formulations and parameters used for evaluation of the biochemical processes of DO and other model variables are all described in "Appendix A and "Appendix B", respectively. Initial estimates for biological parameters were mainly from Nakata (1993) and Horiguchi and Nakata (1994), and then tuned to reproduce the DO concentration during the summer stratified season. Initial POC_B and PHY_B concentrations were set to zero. Initial concentrations of other variables were set using the in situ observational data by the Ministry of the Environment (2002).

The effects of tidal flat emersion/submersion on biochemical processes are also included. The emersion time of each mesh is obtained from the tidal level that is calculated in the hydrodynamics model. While the mesh was emerged, the ecological processes in the mesh are set at zero.

Figure 4 shows the comparison between the observed and calculated DO concentration just above the seabed in summer 2007 at Sta. B3 and Sta. P1 (Fig. 1; Yamaguchi et al. 2015). The observed DO concentration in the Ariake Sea showed great variability. The present model succeeded in reproducing such short-time-scale variation of DO concentration with high accuracy.

The simulation considered the loads of POC, DOC and nutrients from the rivers using the $L-Q$ equation (Yamamoto $K$., personal communication). The simulation without the dike construction considered the load from Honmyo River and the simulation with the dike considered the load from the reservoir through the two gates. The load from the reservoir was obtained by the product of the mean water volume discharged through the gates and averaged concentrations of POC, DOC and nutrients of the reservoir water observed by Nagasaki prefecture. To evaluate the fundamental effects of the dike construction on DO concentration, this study applied seasonally averaged constant values as the boundary conditions of the numerical simulation (weather, river volume and loads from the rivers and the reservoir, etc) from June to August, and analyzed the obtained data after reaching a steady state.

\section{Results}

The calculated results were analyzed after reaching a steady state. Figure 5, as an example, shows the time series of DO concentration in the bottom layer at Sta. C (Fig. 1b). DO concentration showed almost periodic variation (quasisteady state) after 90 days with neap-spring tidal variation. The results discussed hereafter were obtained after 90-day calculation.

The dike construction affected the DO concentration in the bottom layer of the inner Ariake Sea, as well as in the bottom layer of Isahaya Bay. Figure 6 shows the horizontal
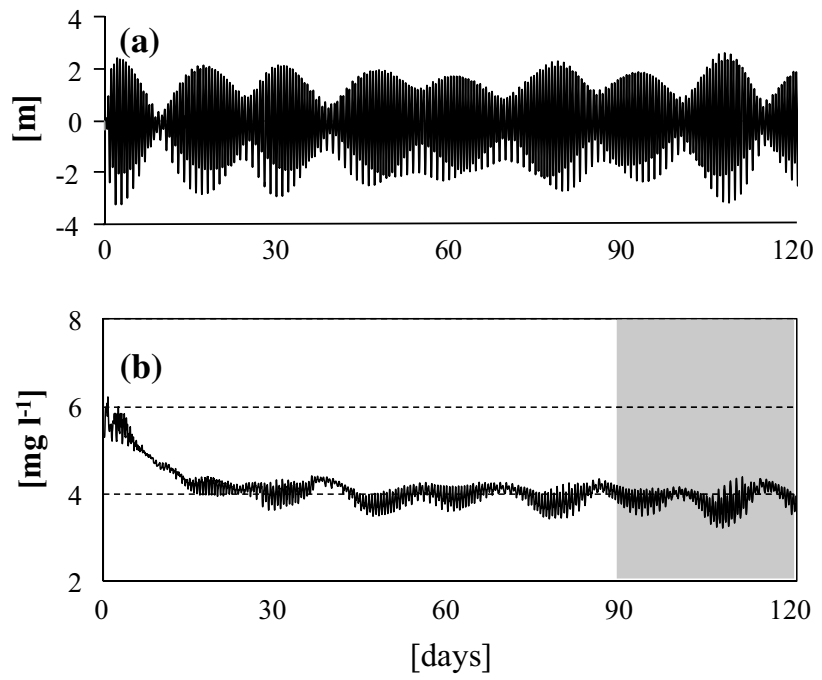

Fig. 5 Time series of a tidal elevation at Sta. Oura and b DO concentration in the bottom layer in the middle of the Ariake Sea (Sta. C). The grey-hatched area indicates the time range for data analysis
Fig. 4 Comparison results of DO concentration just above the seabed at $\mathbf{a}$ Sta. B3 and b Sta. P6 (Fig. 8 in Yamaguchi et al. 2015). The locations of these stations are shown in Fig. 1b (a)

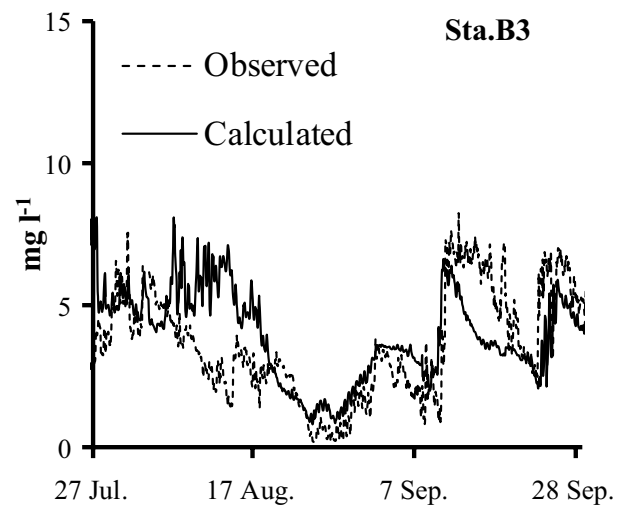

(b)

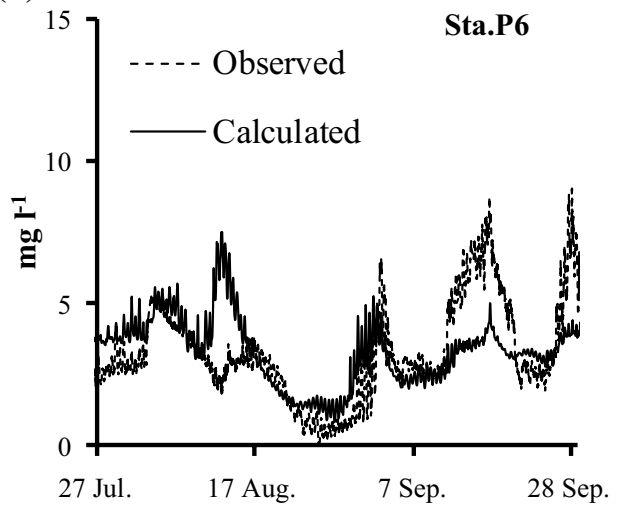



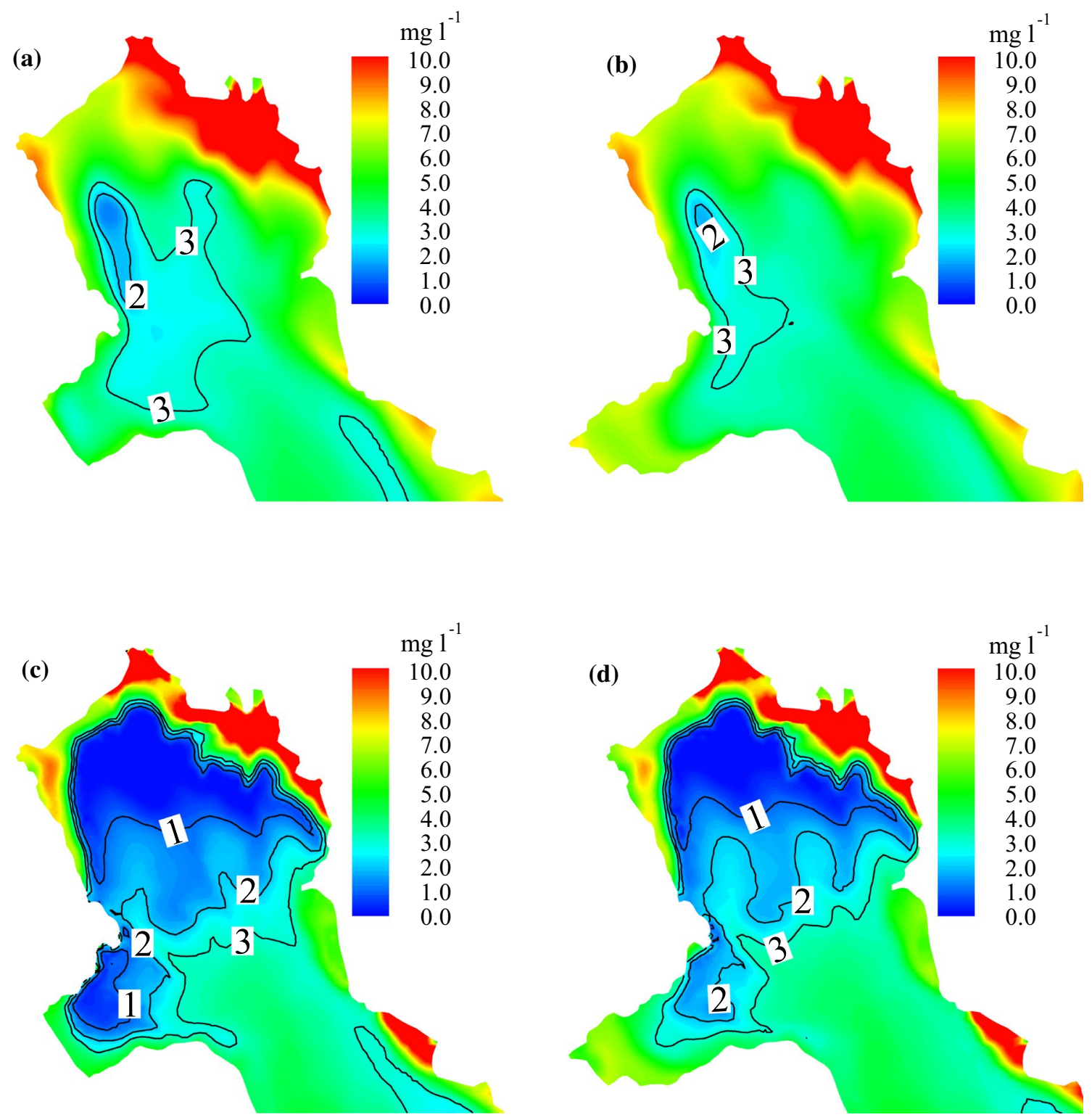

Fig. 6 Horizontal distributions of bottom DO concentration at the head of the Ariake Sea at spring tide (a, b) and neap tide (c, d) with the dike $(\mathbf{a}, \mathbf{c})$ and without the dike $(\mathbf{b}, \mathbf{d})$

distribution of DO concentration in the bottom layer (lowest $\sigma$ layer) during the spring and the neap tide with/without the dike. The area with the bottom DO concentration less than $3.0 \mathrm{mg} \mathrm{l}^{-1}$ (hypoxic area, hereafter) was limited to the area along the Shiota sea channel (Shiota S.C., hereafter, in Fig. 1b) during the spring tide, and it expanded to the entrance of Isahaya Bay and throughout the inner Ariake Sea during the neap tide. The hypoxic area was larger with the dike than without the dike. Figure 7 shows the horizontal distribution of the difference in the bottom DO concentration between with the dike and without it during the spring and the neap tide. To remove the tidal oscillation, 25-h running mean values are shown. Negative values indicate that the DO concentration with the dike was lower than that without the dike. The dike construction decreased the DO concentration in Isahaya Bay (BOX 2) by $2.0 \mathrm{mg}^{-1}$ during both spring and neap tides. The DO concentration in the inner Ariake Sea also decreased by approximately $0.5 \mathrm{mg}^{-1}$ in the area named BOX 1 during the spring tide and about $1.0 \mathrm{mg} \mathrm{l}^{-1}$ in the area adjacent to the tidal flat margin (BOX 3 ) during the neap tide. The effects of the dike construction on DO concentration were not localized to Isahaya Bay but extended to the innermost area of the Ariake Sea. The DO change due to the dike construction was not detected in areas other than BOX 1 to BOX 3 . Thus, the present study investigates 


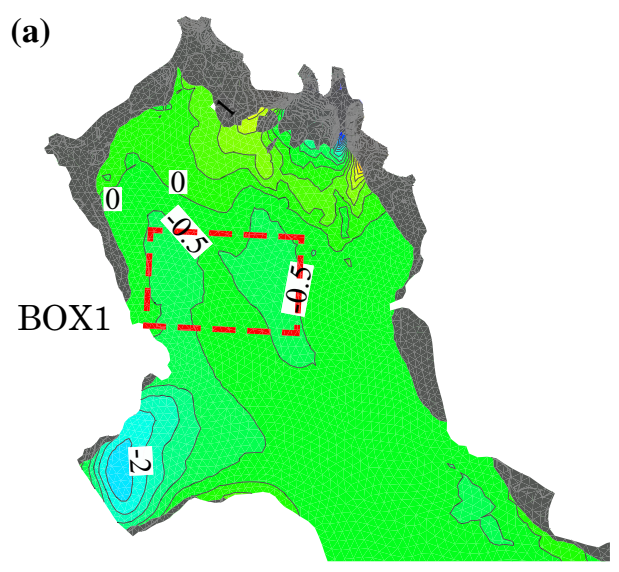

Fig. 7 Horizontal distributions of DO concentration difference in the bottom layer with the dike and without the dike at a spring tide and $\mathbf{b}$ neap tide. Negative values indicate that the dike construction

the mechanisms for the change in DO concentration in these areas, hereafter.

A DO budget analysis was performed to clarify the processes of decreases in DO concentration due to the dike construction. As an example, Fig. 8 shows the time series of the value of each term in Eq. (2) in the lowest $\sigma$ layer of BOX 1 with/without the dike. HorAdv, VerAdv, VerDif and SEABED are DO fluxes due to horizontal advection (sum of the second and third terms in the left side of Eq. 2), vertical advection (the fourth term in the left side), vertical diffusion (the second term in the right side) and consumption by bottom sediment (a part of last term in the right side), respectively. Positive values indicate the supply of DO to the bottom water of BOX 1. Also shown is tidal elevation at Sta. Oura (Fig. 1b). HorAdv, VerAdv and VerDif have spring-neap tidal variation, and SEABED does not. The differences in each term with the dike construction and without it results in the difference of DO concentration in BOX 1. Figure 9 shows the contribution of each term in Eq. (2) to DO variation in the lowest $\sigma$ layer of BOX 1, BOX 2 and BOX 3 (Fig. 7). The budget analysis was made from the neap tide to the spring tide for BOX 1 and from the spring tide to the neap tide for BOX 2 and BOX 3 . The value of each term is that averaged during the above periods in the unit tons of $\mathrm{O}_{2}$ per day. The decrease in DO concentration of the bottom water of BOX 1 due to the dike construction was caused by the decrease in oxygen supply by vertical diffusion and the increase in oxygen loss by vertical advection. Contrarily, the dike construction increased the DO supply due to the horizontal advection into the bottom layer of BOX 1 . The decrease in DO concentration of BOX 2 due to the dike construction was mainly due to the decrease in DO supply by vertical diffusion. In BOX 3 , the decrease in DO concentration was mainly caused by the decrease in oxygen supply by horizontal advection and the decrease in oxygen transport

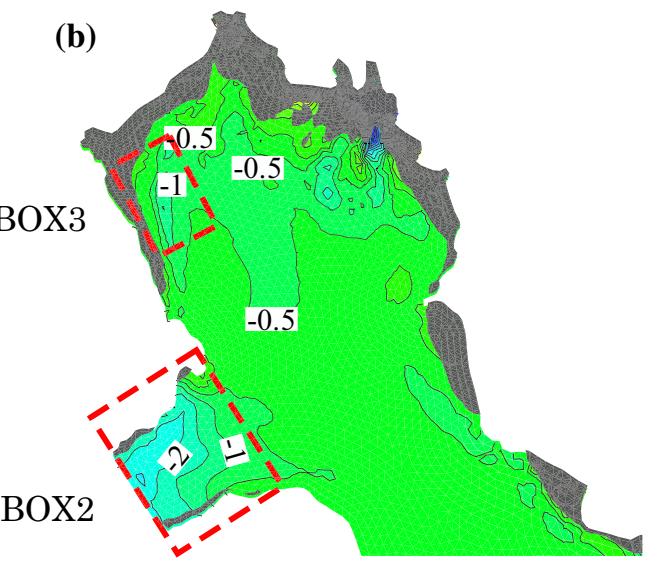

decreased DO concentration. The values are 25 -h running means. The grey area indicates the tidal flat area

by vertical diffusion. The mechanism for DO decrease due to the dike construction was different in each area.

The dike construction intensified the density stratification in a wide area, resulting in the decrease of DO supply due to the vertical diffusion process in BOX 1 and BOX 2 . Figure 10 shows the horizontal distributions of the stratification parameter $\phi$ with/without the dike and the differences $(\mathrm{d} \phi)$ between them. Positive values indicate the intensification of the density stratification due to the dike construction. $\phi$ was large along the channels (Shiota S.C. and Rokkaku S.C.) and submarine valley along Shimabara Peninsula (Fig. 1b). $\mathrm{d} \phi$ was positive around the mouth of Isahaya Bay, the western area of the inner Ariake Sea and in the deep valley along Shimabara Peninsula. Figures 11 and 12 show isopleth diagrams of $\phi, U^{3} / h$ and their difference (subtraction of the values without the dike from those with the dike) along the ISA and ARI lines (Fig. 10c), respectively, during one neap-spring tidal cycle (Fig. $8 \mathrm{a}$ ). $U$ is the vertically averaged velocity and $h$ is the total water depth. $U^{3} / h$ is an indicator of the strength of tidal mixing power (Simpson et al. 1990). The $\phi$ values along two lines decreased during the spring tide and increased during the neap tide. $U^{3} / h$ values decreased during the neap tide and increased during the spring tide. Along the ISA line, the difference in $U^{3} / h$ between with the dike and without it was large, especially in front of the dike during the spring tide. This indicates that the dike construction weakened the tidal mixing in Isahaya Bay. Along the ARI line, the dike construction weakened the tidal mixing in the south of Sta. A (Fig. 10c). Correspondingly, the density stratification was intensified there by the dike construction. On the other hand, in the north of Sta. A, despite the dike construction hardly weakening the tidal mixing, the density stratification was intensified (Fig. 10c, f). 
Fig. 8 Time series of the value of each term in Eq. (2) in the lowest $\sigma$ layer in BOX 1 with/without the dike. Also shown is tidal elevation at Sta. Oura (a). HorAdv, VerAdv, VerDif and SEABED are contributions to DO concentration variation (unit: $\mathrm{t} \mathrm{h}^{-1}$ ) due to horizontal advection (b sum of the second and third terms in the left side of Eq. 2), vertical advection (c fourth term in the left side), vertical diffusion ( $\mathbf{d}$ second term in the right side) and consumption by bottom sediment (e), respectively. Positive values mean the supply of DO to the bottom water in BOX 1, and vice versa

\section{Discussion}

\subsection{Validation of the present model}

The purpose of this study was to investigate the effect of the dike construction in Isahaya Bay on DO concentration in the Ariake Sea by using numerical simulation. The dike construction intensified the density stratification in Isahaya Bay, the western area of the inner Ariake Sea and in the deep valley along Shimabara Peninsula (Fig. 10). DO concentration decreased in Isahaya Bay and the inner Ariake Sea with the dike construction through the processes described in the previous section (Fig. 9). The dike constructed in Isahaya Bay affected the DO concentration over a wide area of the Ariake Sea.

Matsukawa et al. (2014) investigated the effects of the dike construction using monthly monitoring data by the Saga Ariake Fisheries Promotion Center from 1973 to 2009. They reported intensification of density stratification and decrease in bottom DO concentration in the inner Ariake Sea due to the dike construction. The area with the intensified stratification and the decrease of bottom DO concentration reported by Matsukawa et al. (2014) mostly coincides with that of this study (Figs. 7, 10). Hayami and Fujii (2017) also analyzed the same monthly monitoring data in the inner Ariake Sea and reported that the density difference between the surface and the bottom waters became larger after late 1990s than before in the inner Ariake Sea. This result is also consistent with the result in this study since the dike was constructed in 1997. These facts give confidence to the validity of the present numerical simulation. Matsukawa et al. (2014) suggested that the dike construction induced red tides through the increase of nutrient outflow from Isahaya Bay and the increase in organic matter flux to the bottom due to the red tides decreased DO concentration in the inner Ariake Sea. The present study, however, showed that the decrease in DO supply due to the vertical diffusion process caused the decrease of DO concentration and there was a very small difference in DO consumption by the organic matter decomposition between with the dike and without it (Fig. 9a, c) in the inner Ariake Sea. In BOX 3, DO consumption by the organic matter decomposition decreased with the dike construction rather than increased. Matsukawa et al. (2014) also suggested that outflow of low-DO water in Isahaya Bay (a)

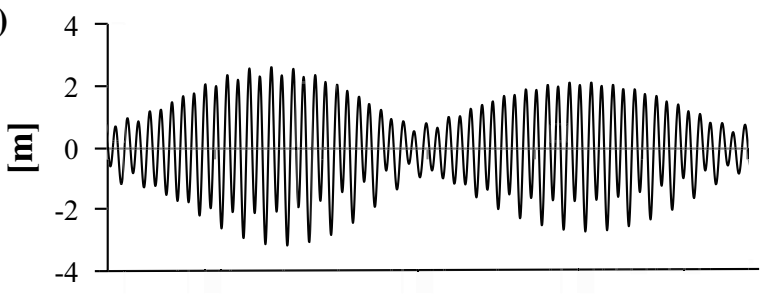

(b)
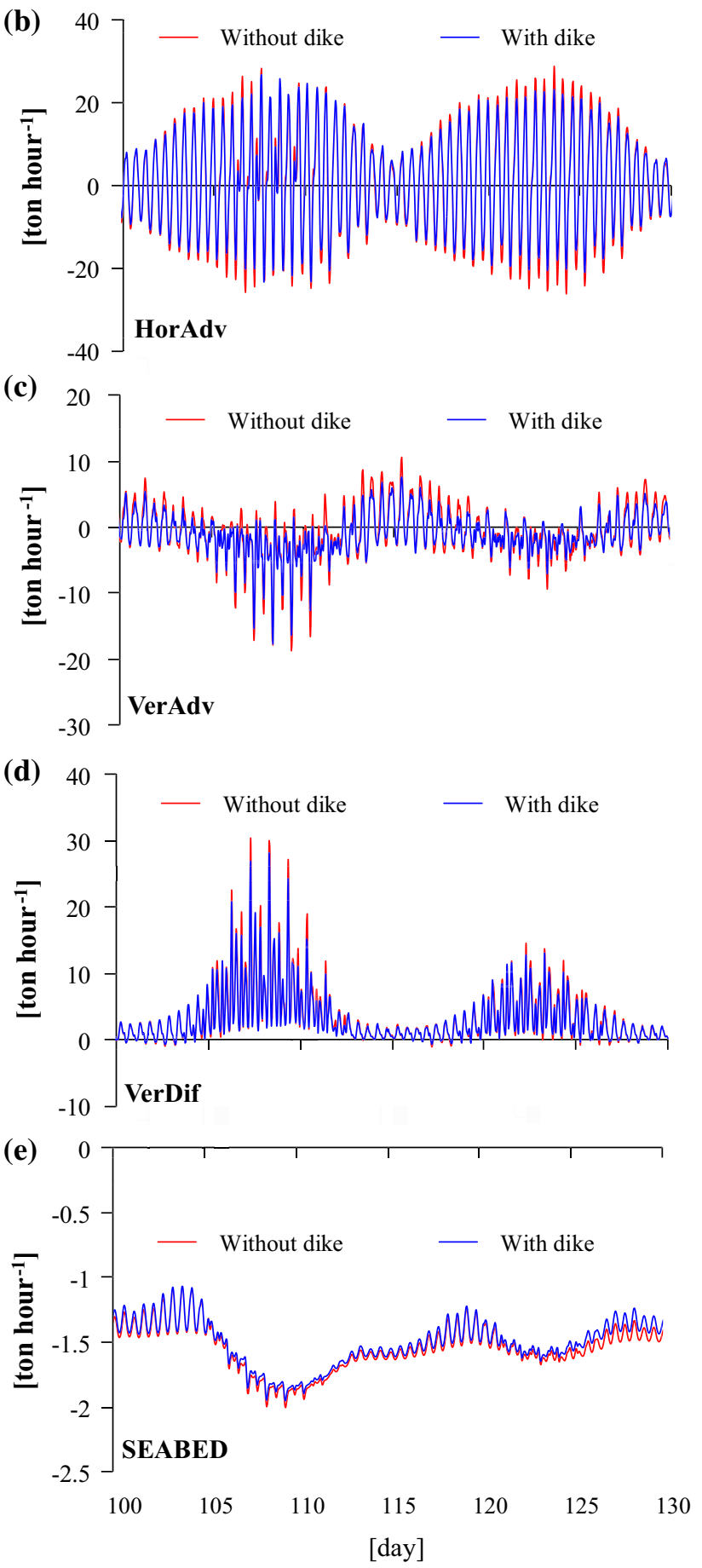
Fig. 9 Results of DO budget in a BOX 1, b BOX 2 and c BOX 3. Positive values indicate inflow or production of DO and negative outflow or consumption. HorAdv DO flux due to horizontal advection, VerAdv vertical advection, HorDIf horizontal diffusion, VerDif vertical diffusion, OYSTER respiration of oyster reef, SEABED consumption by bottom sediment, $P H Y \_$prod production by photosynthesis, PHY_Consump respiration of phytoplankton, $\mathrm{ZOO}$ respiration of zooplankton, $P O C$ consumption by decomposition of particulate organic matter in water column, $D O C$ consumption by dissolved organic matter decomposition in water column, nitrification consumption related to nitrification processes

decreased DO concentration in the inner Ariake Sea. In the present study, however, the DO supply by the horizontal advection in BOX 1 increased with the dike construction. Figure 13 shows the horizontal residual currents in the surface and bottom layer and the difference due to the dike construction during the spring tide. The structure of the residual currents showed typical estuarine circulation flowing outward in the upper layer and inward in the lower layer from the deep channel along Shimabara Peninsula to Shiota S.C. The structure of residual current during the neap tide was the same as that during the spring tide. This pattern of residual currents was observed by Hayami et al. (2006). The dike construction intensified the outward residual current in the surface layer and inward one in the bottom layer of the middle Ariake Sea and around the mouth of Isahaya Bay. This increased the DO supply by the horizontal advection in BOX 1 with the dike construction.

\subsection{Effect of the dike construction on DO concentration}

The dike construction intensified density stratification in the western inner Ariake Sea (BOX 1) and Isahaya Bay (BOX 2 ), leading to the decrease of DO concentration with the dike through the weakening of DO supply due to the vertical mixing process (Fig. 9a, b, respectively). Tidal stirring is one of the most energetic mechanisms mixing the water column in the Ariake Sea. Figure 14 shows the horizontal distribution of the length of the major axis of the $\mathrm{M}_{2}$ tidal ellipse with and without the dike construction and the difference between them. In drawing the tidal ellipses, a time series of vertically averaged velocity (barotropic current) was used. $\mathbf{M}_{2}$ is the largest tidal constituent in the Ariake Sea. The dike construction weakened the tidal current in Isahaya Bay and in the middle of the Ariake Sea, as reported previously by Tai and Yano (2008) and Manda and Matsuoka (2006). The weakened tidal current reduced the tidal mixing there and intensified the density stratification (Figs. 11, 12). In Isahaya Bay, the intensification of density stratification was a critical process for hypoxia/anoxia generation (Yamaguchi and Kyozuka 2006). Therefore, the dike construction exerted a significant impact on the generation of hypoxia/anoxia in
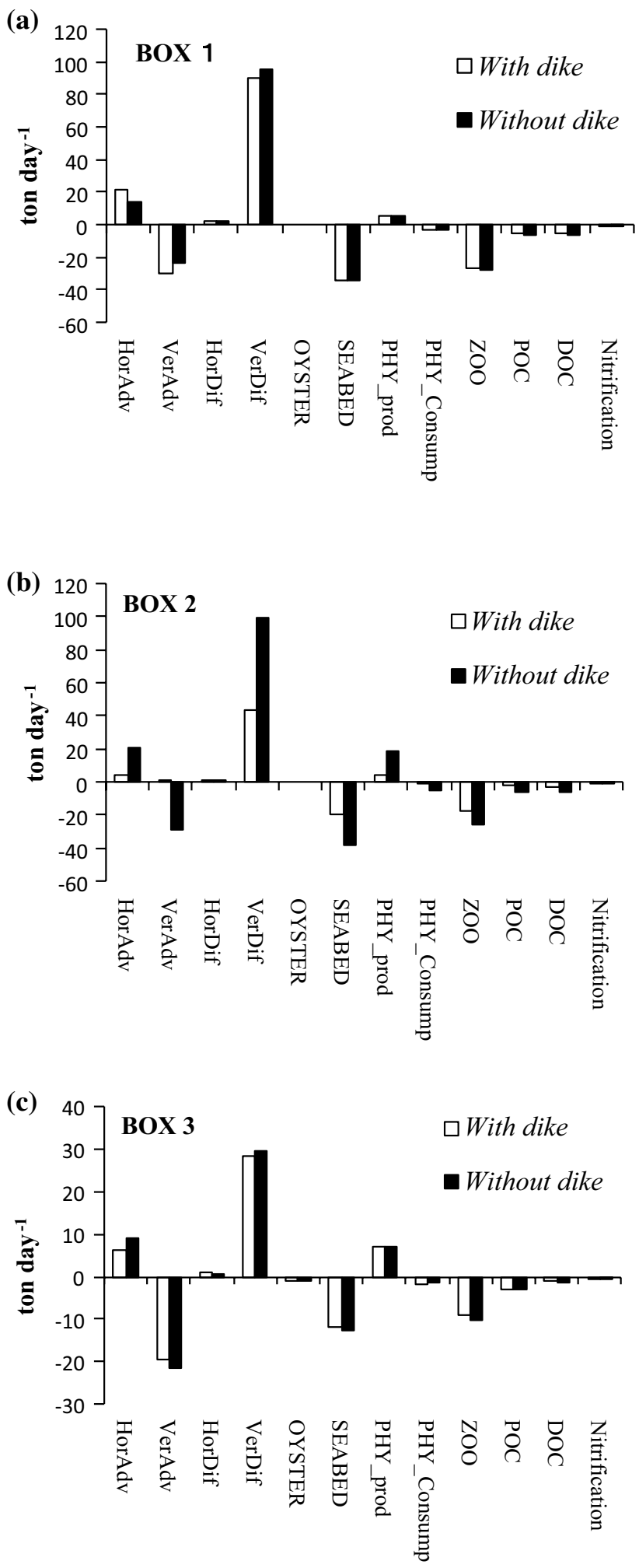

Isahaya Bay (BOX2). On the other hand, the dike construction barely weakened the tidal mixing in the inner Ariake Sea including BOX 1 (Fig. 12f). Simpson et al. (1990) pointed out that the intensification of the density stratification was mainly caused by two mechanisms. One is the 


\section{With dike}

(a)

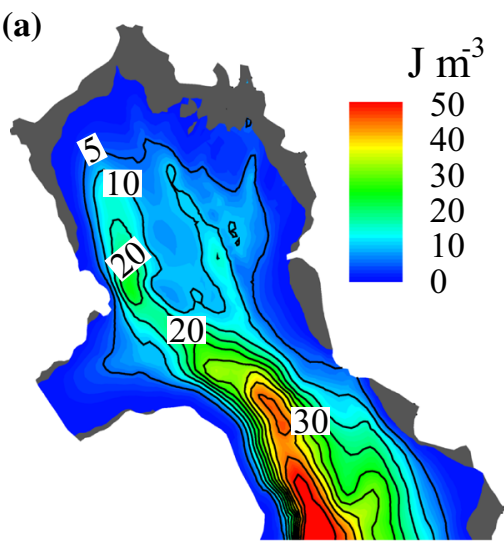

(d)

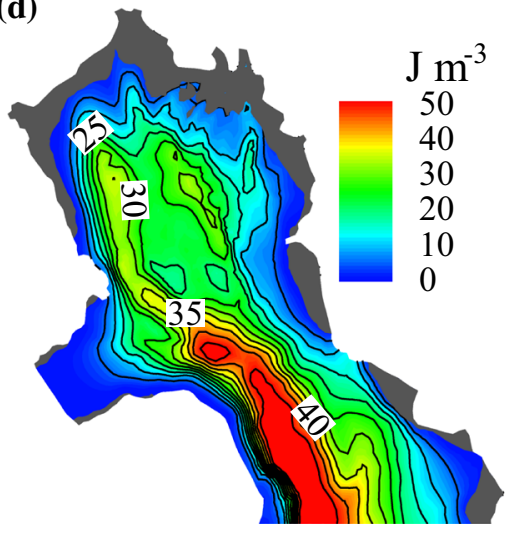

Without dike
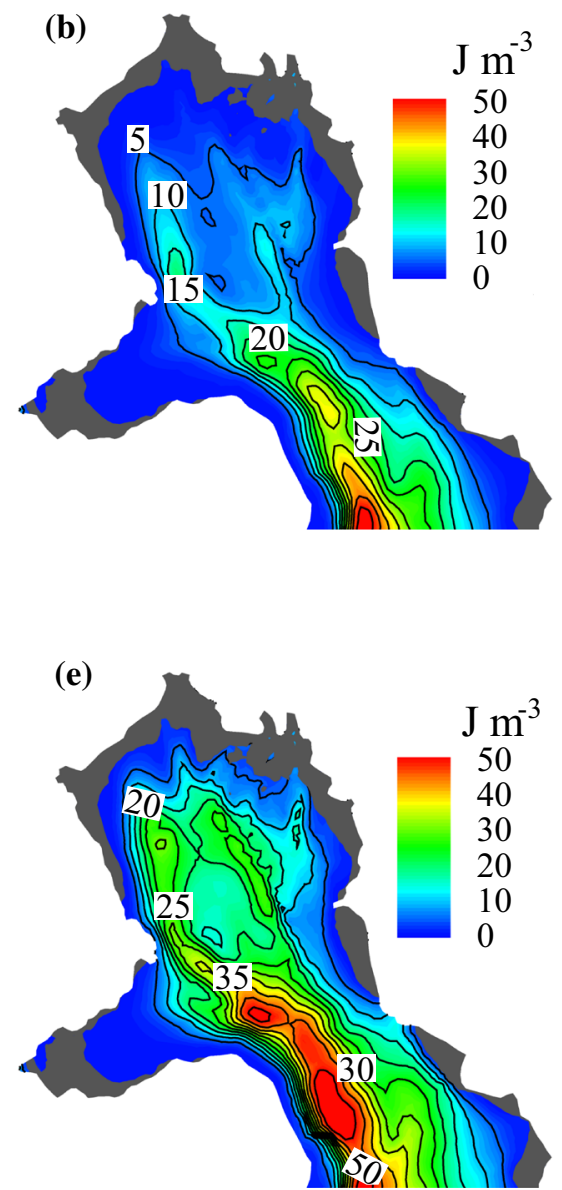

(c)
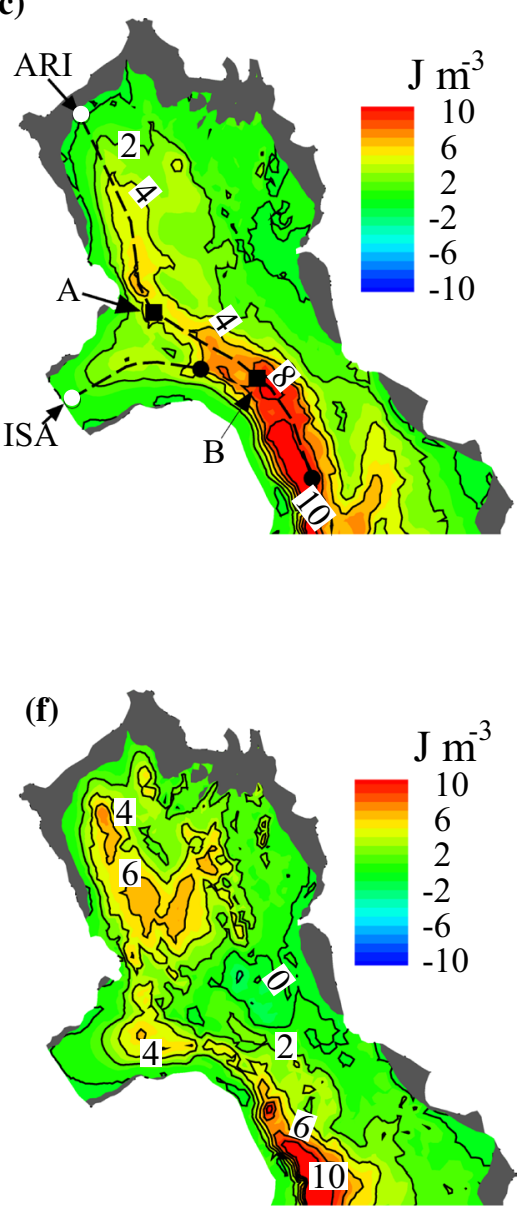

Fig. 10 Horizontal distribution of stratification strength and the difference $(\mathbf{c}, \mathbf{f})$ between with the dike (a, d) and without it (b, e) at the spring tide (a-c) and the neap tide (d-f). Positive values indicate intensification of stratification due to the dike construction

weakening of the mixing power of the water column, and the other is the strengthening of the horizontal advection due to the residual current. The tidal mixing was almost unchanged by the dike construction in the inner Ariake Sea (Fig. 12). Therefore, the former process was not the cause for the intensification of density stratification in this area. The dike construction weakened the tidal current in the middle of the Ariake Sea, especially around point B in Fig. 10. It led to the weakening of the tidal mixing there (Fig. 12). The reduced vertical mixing enhances the baroclinic circulation and stratification (Linden and Simpson 1988). Indeed, the outward residual current in the surface layer and inward one in the bottom layer were strengthened in the middle of the Ariake Sea by the dike construction (Fig. 13). Therefore, the weakening of the tidal mixing due to the dike construction strengthened the estuarine circulation and intensified the density stratification in the inner Ariake Sea.

The decrease in DO concentration in the bottom of BOX 3 due to the dike construction resulted from the difference in DO supply by the horizontal advection (Fig. 9). There are two potential reasons. One is the change in the strength of the residual circulation. Another is the change in DO concentration of the water intruding into the bottom of BOX 3 . The change in residual current due to the dike construction was very small and random in the inner Ariake Sea (Fig. 13d). The former change, therefore, is not the cause for the DO decrease in the area of BOX 3. The residual currents flowed outward in the upper layer and inward in the lower layer from the deep valey along Shimabara Peninsula to Shiota S.C. (Fig. 13a, b). This pattern of residual currents transports the bottom water in the southern area toward the sea head. As shown in Fig. 7a, the dike construction decreased the DO concentration in the bottom layer of BOX 1 during the spring tide. The transportation of this lower-DO water mass resulted in the decrease of DO supply to the bottom layer of BOX 3 . The cause for the DO decrease in BOX 3 is the decrease in DO concentration of the water intruding from the southern part of the inner Ariake Sea. 


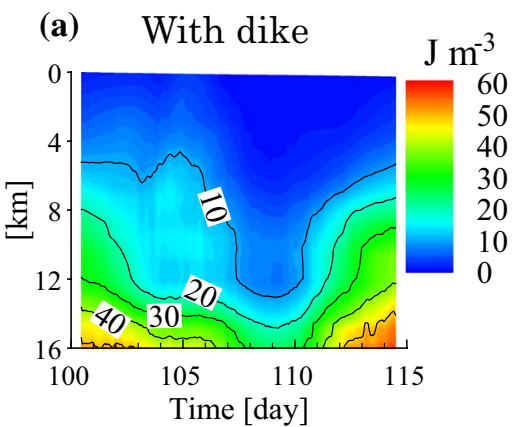

(d)

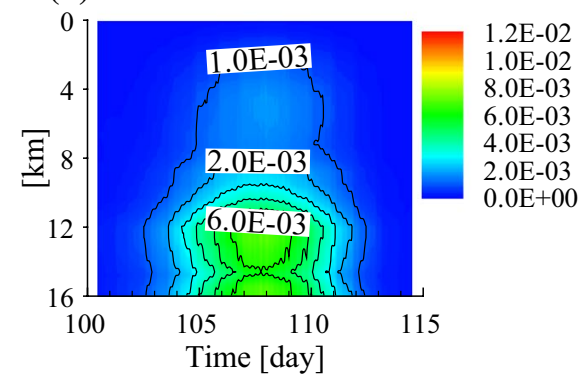

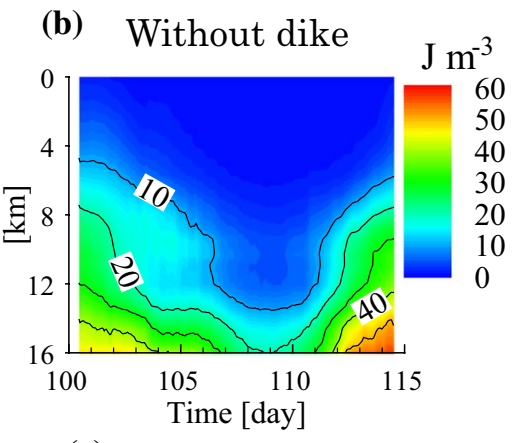

(e)

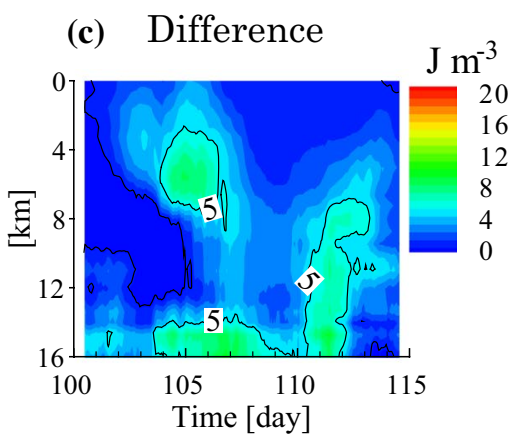

(f)
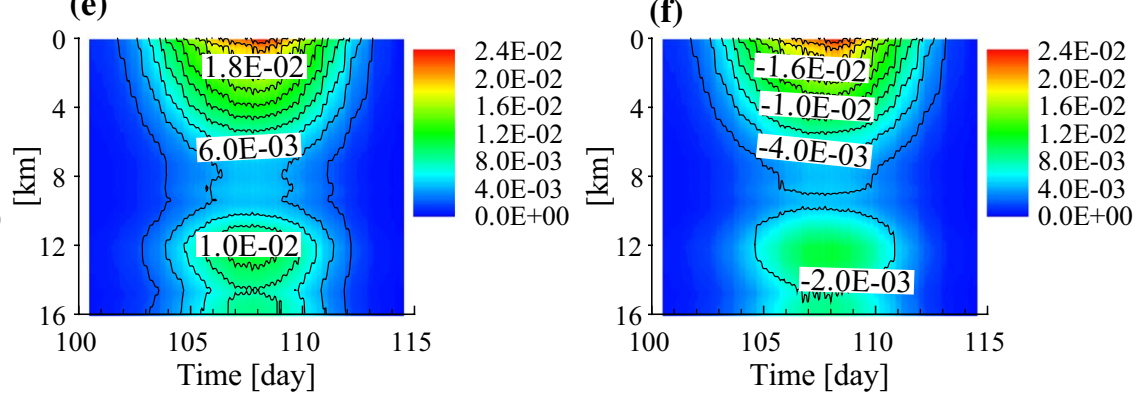

Fig. 11 Isopleth diagrams of $\phi(\mathbf{a}, \mathbf{b}), U^{3} / h(\mathbf{d}, \mathbf{e})$ and the difference $(\mathbf{c}, \mathbf{f})$ between with the dike $(\mathbf{a}, \mathbf{d})$ and without it $(\mathbf{b}, \mathbf{e})$ along the ISA line during one neap-spring tidal cycle. The location of the ISA line is shown in Fig. 10. The difference was calculated by subtracting the values without the dike construction from the values with it. Values

\subsection{Limitation of the present model}

The result of the present numerical simulation differs from that of Nagao et al. (2010) in which DO concentration decreased only in Isahaya Bay because of the dike construction. One of the reasons for this discrepancy is the different setting of the numerical simulation. Nagao et al. (2010) evaluated the effect of geographical modifications between 1990 and 2001 (mainly the dike and Kumamoto new port) on the DO field in the Ariake Sea using numerical simulation. He conducted year-round calculations in 2001 and applied boundary conditions (e.g. river water volume, weather) that varied from hour to hour. Moreover, the riverine load of nutrients and COD, tidal amplitude at the open boundary, bivalve biomass and mean sea level are different between 1990 and 2001. We conducted the steady-state simulation applying the seasonally averaged boundary conditions in the summer stratified season. Thus, the effects of the dike construction manifested in different ways. Since Nagao et al. (2010) did not clarify the mechanisms that caused the DO difference, further studies are needed that consider the unsteady state conditions.

Sasaki et al. (2003) reported that inflow of chemical oxygen demand (COD), total nitrogen (TN), and total phosphorus (TP) to the Isahaya Bay increased significantly after the in the $y$-axis of each figure are the distances $(\mathrm{km})$ from the starting point open circle shown in Fig. 10 and those in the $x$-axis are the calculation time (day). $U$ is the vertically averaged velocity and $h$ is the total water depth

dike construction and promoted hypoxia/anoxia formation by the increase of DO consumption due to the deposition of organic matter on the seabed in the bay. Our simulation, however, revealed that the decrease in DO concentration in Isahaya Bay (BOX 2) was predominantly because of the decrease in DO supply by the vertical diffusion process ("VerDIf" in Fig. 9), and not the increase in DO consumption by organic matter decomposition ("SEABED", "POC" and "DOC" in Fig. 9). The decomposition rate of organic matter in the ecosystem model was a function of DO concentration (see "Appendix A"), decreasing with the decrease in DO concentration. As shown in Fig. 7, DO concentration in Isahaya Bay with the dike was very low during both the spring and the neap tide compared to that without the dike. This decreased the DO consumption rate due to organic matter decomposition. Sasaki et al. (2003) also reported that strong currents at times of water discharge through the gates increased the COD load by resuspension of bottom sediment. Hayami and Hamada (2015) reported that gate-opening generated complicated flow in Isahaya Bay. Since these were not considered in the present numerical simulation, future study should consider these effects for more accurate evaluation of the effects of the dike construction.

The present study evaluated the effects of the dike construction under seasonally averaged conditions in the 
(a)

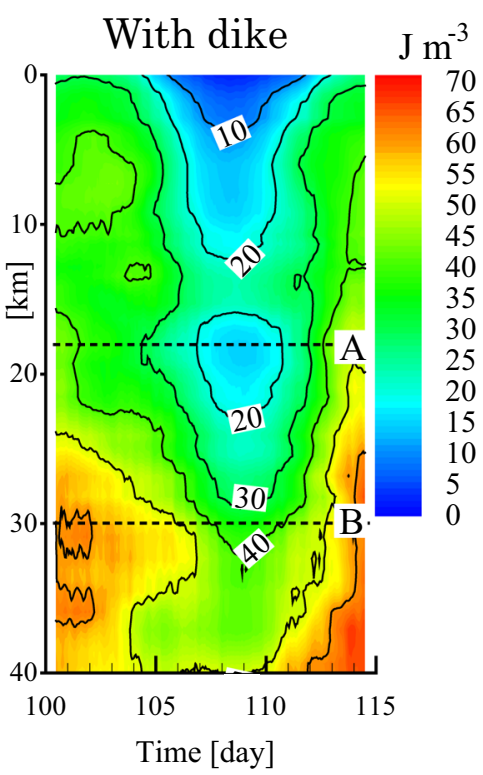

(d)

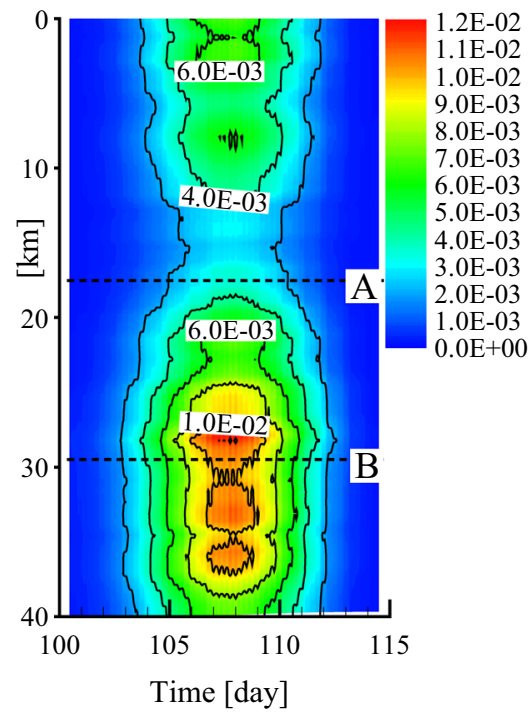

(b)

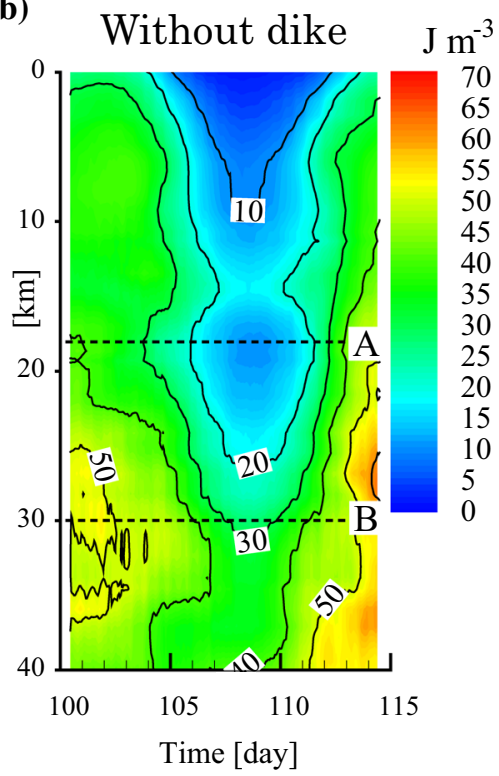

(e)

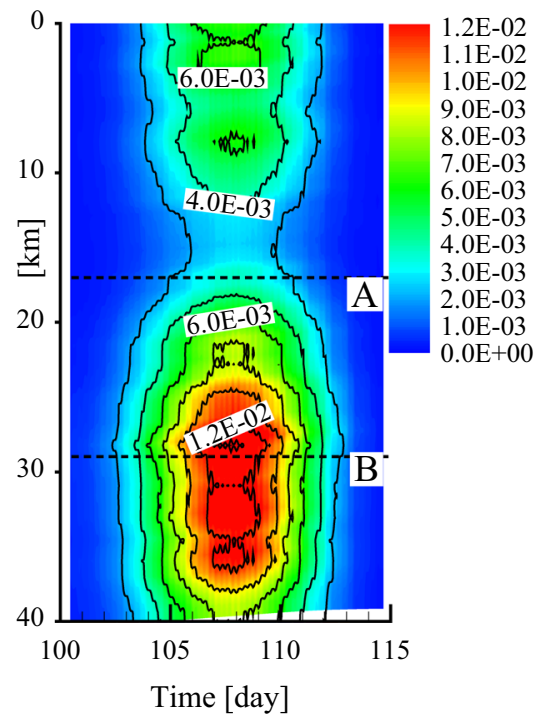

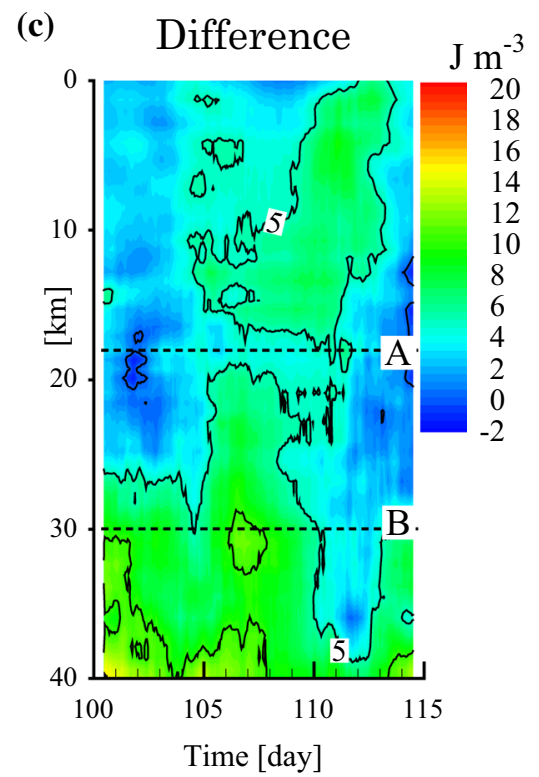

(f)

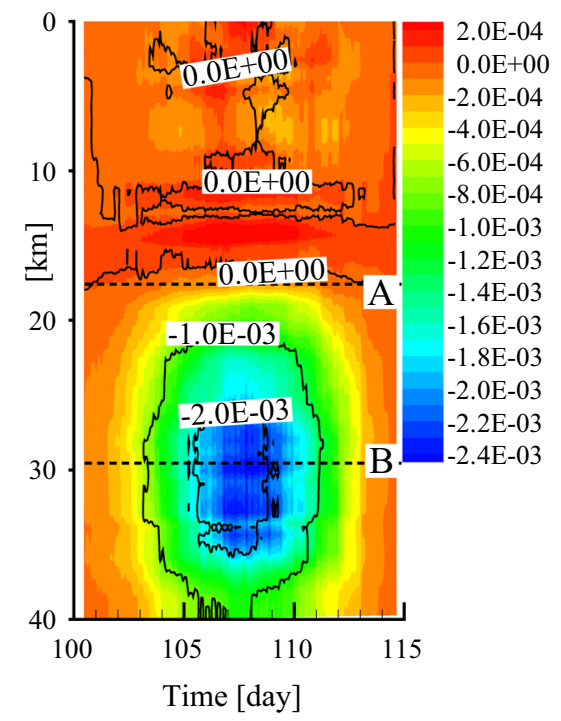

Fig. 12 Isopleth diagrams of $\phi(\mathbf{a}, \mathbf{b}), U^{3} / h(\mathbf{d}, \mathbf{e})$ and the difference $(\mathbf{c}, \mathbf{f})$ between with the dike $(\mathbf{a}, \mathbf{d})$ and without it $(\mathbf{b}, \mathbf{e})$ along the ARI line during one neap-spring tidal cycle. Values in the $y$-axis of each figure are the distances $(\mathrm{km})$ from the starting point open circle in

stratified summer season. Thus, the results obtained in this study represent the fundamental impact of the dike construction on DO concentration. We acknowledge, however, that the steady-state calculation has several limitations. The actual biotic/abiotic environments vary steadily depending
Fig. 10 and those in the $x$-axis are the calculation time (day). $U$ is the vertically averaged velocity and $h$ is the total water depth. Locations of Sta. A and Sta. B (the dashed lines) in Fig. 12 are also shown in Fig. 10

on hour-to-hour variations in the surrounding environments, such as river volume, weather conditions, etc. In Japan, we have a heavy rain season called "Tsuyu" every early summer, and it increases the river water inflow into the Ariake Sea. The great amount of fresh water with high nutrients 
Fig. 13 Residual flow in the surface (a) and the bottom layer (b) at spring tide with the dike construction and its difference in residual flow with the dike and without the dike in the surface $(\mathbf{c})$ and the bottom layer $(\mathbf{d})$
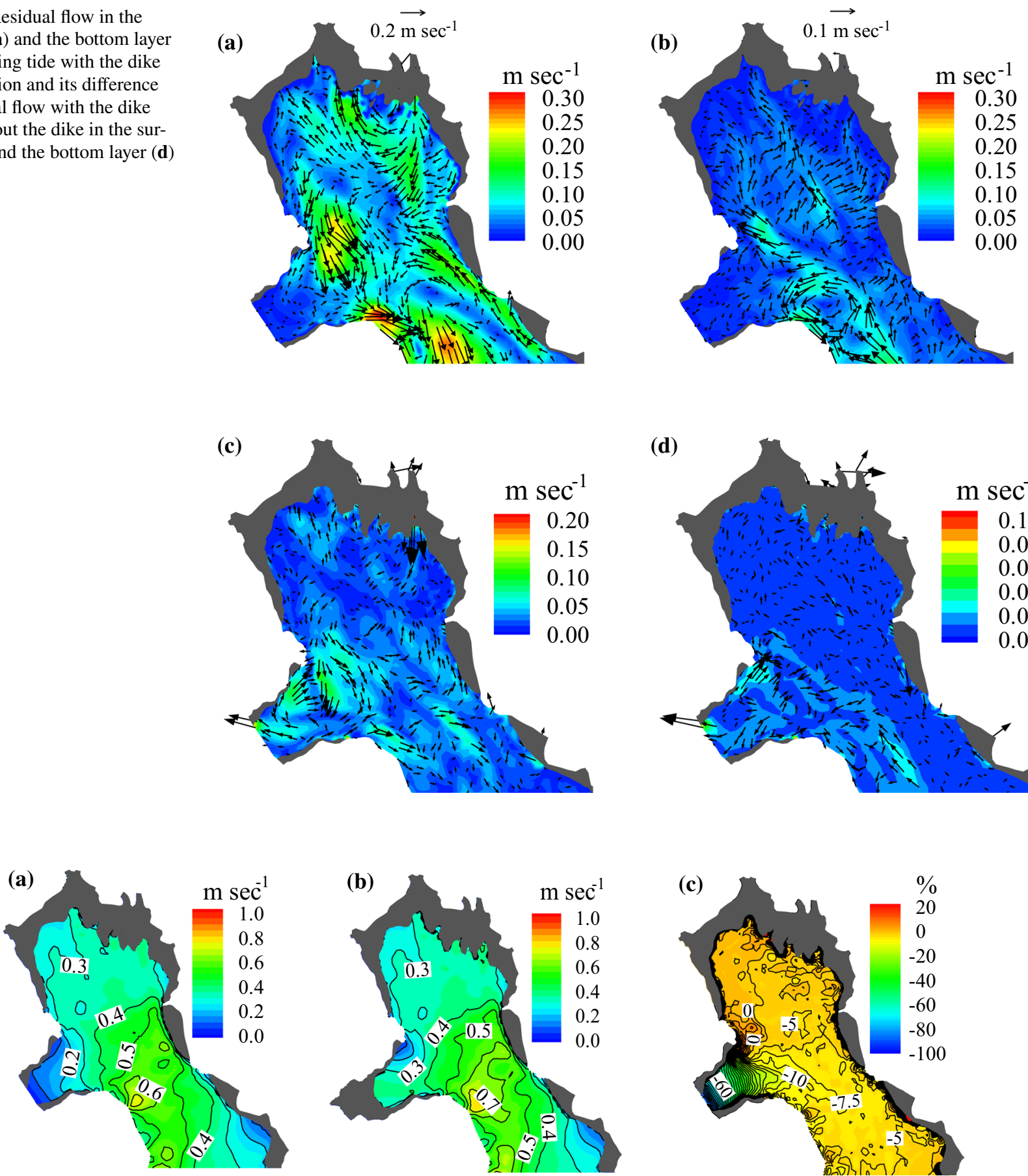

Fig. 14 Horizontal distribution of the length of the major axis of the M2 tidal ellipse $\mathbf{a}$ with the dike construction, $\mathbf{b}$ without it, and $\mathbf{c}$ the difference between them

induces red tides, and the phytoplankton-derived organic matter consume DO, sometimes leading to hypoxia/anoxia. Furthermore, these events have inter-annual variations. Future studies need to consider such unsteady-state conditions to evaluate the effects of the dike construction on DO concentration more comprehensively.

\section{Conclusions}

Steady-state calculations of summertime neap-spring tidal variations in this study indicated that the Isahaya dike construction has affected DO concentration over a wider area than previously reported. For the first time, we used 
numerical simulations to show how the dike construction affected DO concentrations in Isahaya Bay and the inner Ariake Sea. In Isahaya Bay, DO concentration decreased by more than $2.0 \mathrm{mg} \mathrm{l}^{-1}$ due to the decrease in DO supply caused by vertical diffusion, with the reduction in the tidal current and an intensification of density stratification. The area with the decrease of bottom DO concentration due to the dike construction extended to the area adjacent to the tidal flat margin of the inner Ariake Sea, where severe hypoxia or anoxia was generated every summer. The dike construction affected DO concentration here by decreasing the DO concentration of the water intruding from the southern part of the inner Ariake Sea. The decrease of DO concentration in the intrusion water was caused by reduction in the vertical diffusive supply of oxygen due to the intensified stratification. This, in turn, was a result of enhanced estuarine circulation caused by the dike construction.

Estuarine and coastal environments are affected by multiple anthropogenic pressures and stresses owing to their nature as a focal area for impacts from both the land and the sea. This study shows that the dike construction (an anthropogenic local impact in a small bay) can affect DO concentration over a wide area through the complicated processes. The effects of the dike construction on the estuarine environments should be reconsidered more comprehensively in the future.

Acknowledgements We appreciate Fukuoka Fisheries and Marine Technology Research Center, Ariake-kai Laboratory, Saga Ariake Fisheries Promotion Center, Kumamoto Prefectural Fisheries Research Center, Nagasaki Prefectural Institute of Fisheries and the Ministry of the Environment for providing data. Also, we thank Dr. Koichi Yamamoto for providing the data set of terrestrial loads. This research was financially supported by the Ministry of Education, Culture, Sports, Science and Technology and Saga University as a part of the COMPAS (Cooperative Monitoring Program of Ariake Sea) project.

Open Access This article is distributed under the terms of the Creative Commons Attribution 4.0 International License (http://creativecomm ons.org/licenses/by/4.0/), which permits unrestricted use, distribution, and reproduction in any medium, provided you give appropriate credit to the original author(s) and the source, provide a link to the Creative Commons license, and indicate if changes were made.

\section{Appendix A: Formulation of biochemical processes in the ecosystem model}

The formulations of biochemical processes used in the ecosystem model are shown in Table 3. 
Table 3 Formulations of biochemical processes in the ecosystem model

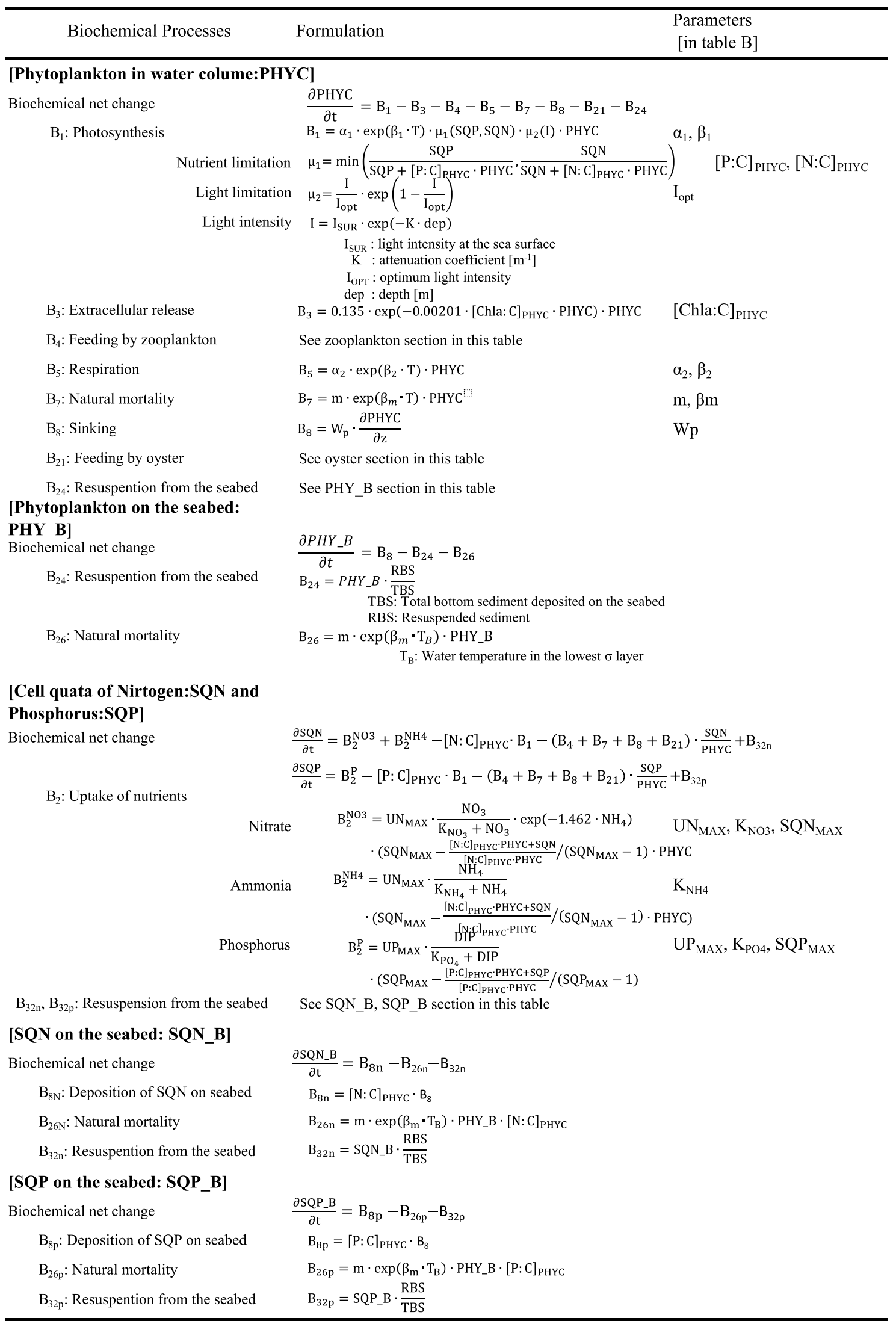


Table 3 (continued)

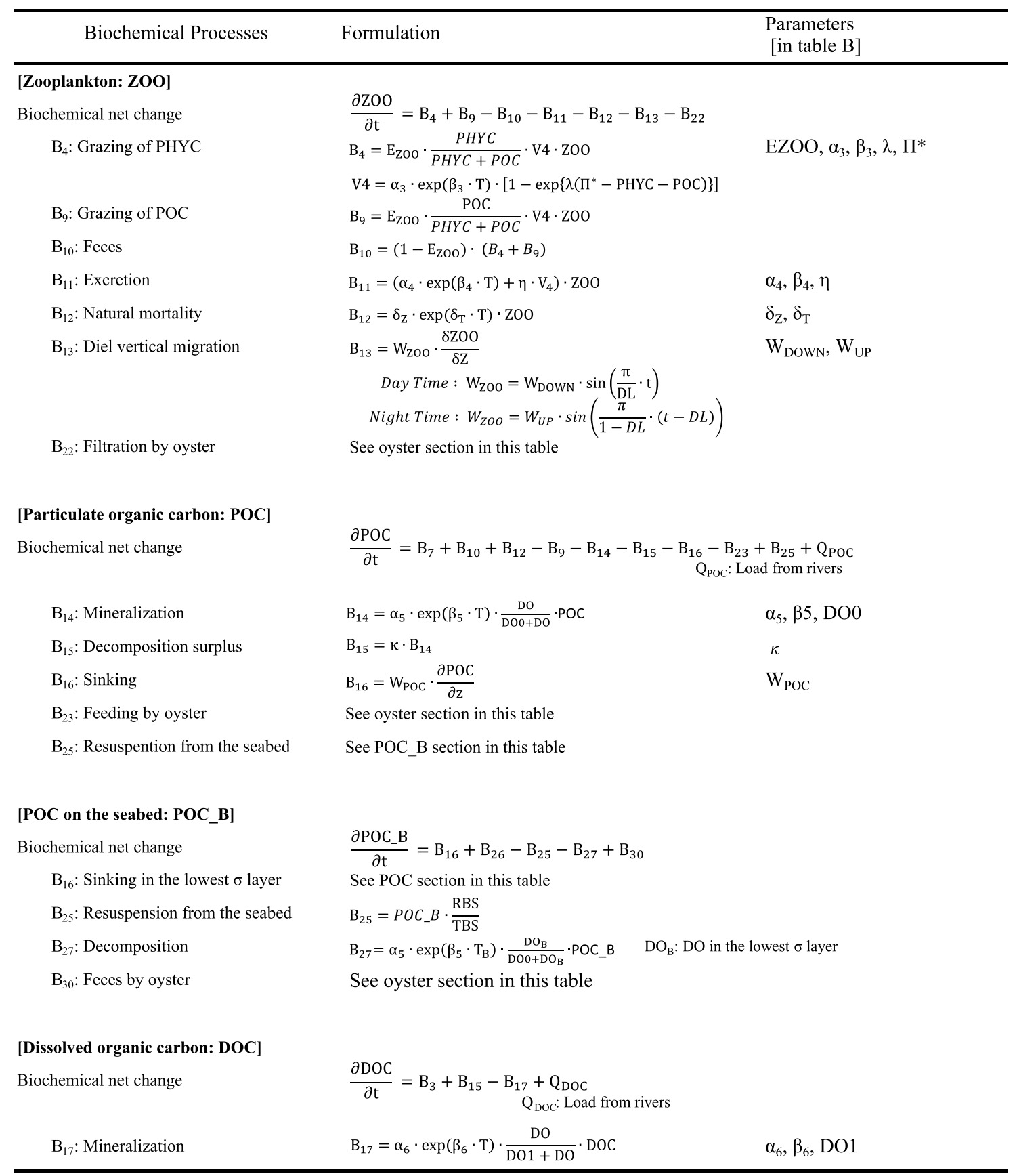


Table 3 (continued)

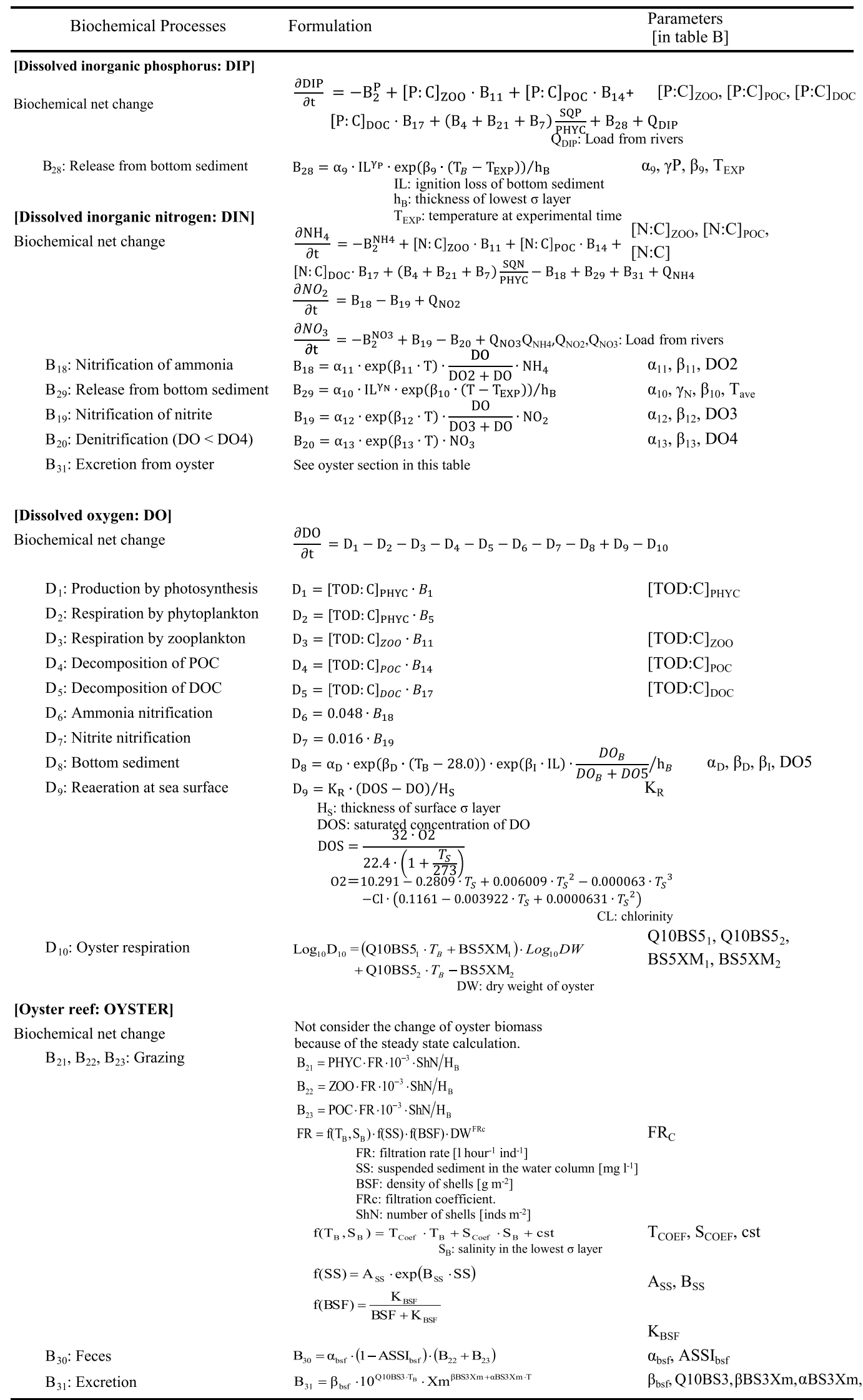




\section{Appendix B: Parameters used in the ecosystem model}

Parameters used in the formulations of biochemical processes of the ecosystem model in this study are listed in Table 4.

Table 4 Parameters of phytoplankton dynamics used in the ecosystem model

\begin{tabular}{|c|c|c|c|}
\hline Parameters & Definitions & Unit & Value \\
\hline$\alpha_{1}$ & Maximum growth rate & day $^{-1}$ & 0.72 \\
\hline$\beta_{1}$ & Temperature coefficient for growth & & 0.0633 \\
\hline$\alpha_{2}$ & Respiration rate & day $^{-1}$ & 0.01 \\
\hline$\beta_{2}$ & Temperature coefficient for respiration & & 0.0693 \\
\hline$I_{\mathrm{OPT}}$ & Optimum light intensity for photosynthesis & $\mathrm{W} \mathrm{m}^{-2}$ & 96.898 \\
\hline$[\mathrm{P}: \mathrm{C}]_{\mathrm{PHYC}}$ & Carbon-to-phosphorus ratio & & 0.000806 \\
\hline$[\mathrm{N}: \mathrm{C}]_{\mathrm{PHYC}}$ & Carbon-to-nitrogen ratio & & 0.011429 \\
\hline$[\text { Chla:C }]_{\mathrm{PHYC}}$ & Carbon-to-chlorophyll- $a$ ratio & & 0.0105 \\
\hline$W_{\mathrm{P}}$ & Sinking velocity & $\mathrm{m}_{\text {day }}{ }^{-1}$ & 0.1 \\
\hline$m$ & Natural mortality rate & day $^{-1}$ & 0.05 \\
\hline$\beta_{\mathrm{m}}$ & Temperature coefficient for death & & 0.0693 \\
\hline $\mathrm{UP}_{\mathrm{MAX}}$ & Maximum uptake rate for phosphorus & day $^{-1}$ & 18 \\
\hline $\mathrm{UN}_{\mathrm{MAX}}$ & Maximum uptake rate for nitrogen & day $^{-1}$ & 6 \\
\hline$[\text { TOD:C }]_{\mathrm{PHYC}}$ & Carbon-to-DO ratio & & 0.0015 \\
\hline $\mathrm{SQP}_{\mathrm{MAX}}$ & Maximum cell quota for phosphorus & $\mu \mathrm{M}$ & 16 \\
\hline $\mathrm{SQN}_{\mathrm{MAX}}$ & Maximum cell quota for nitrogen & $\mu \mathrm{M}$ & 8 \\
\hline$K_{\mathrm{PO} 4}$ & Half saturation constant for phosphorus uptake & $\mu \mathrm{M}$ & 0.1 \\
\hline$K_{\mathrm{NH} 4}$ & Half saturation constant for $\mathrm{NH}_{4}-\mathrm{N}$ uptake & $\mu \mathrm{M}$ & 0.714 \\
\hline$K_{\mathrm{NO} 3}$ & Half saturation constant for $\mathrm{NO}_{3}-\mathrm{N}$ uptake & $\mu \mathrm{M}$ & 0.143 \\
\hline$E_{\mathrm{ZOO}}$ & Assimilation efficiency & & 0.7 \\
\hline$\alpha_{3}$ & Maximum growth rate & day $^{-1}$ & 0.18 \\
\hline$\beta_{3}$ & Temperature coefficient for growth & & 0.0693 \\
\hline$\lambda$ & Ivlev's constant & & 0.01 \\
\hline$\Pi^{*}$ & Threshold value for food concentration & $\mathrm{mgC} \mathrm{m} \mathrm{m}^{-3}$ & 50 \\
\hline$\alpha_{4}$ & Respiration rate & day $^{-1}$ & 0.0214 \\
\hline$\beta_{4}$ & Temperature coefficient for respiration & & 0.0637 \\
\hline$\eta$ & Energy consumption ratio for feeding behavior & & 0.4 \\
\hline$\delta_{Z}$ & Death rate & day $^{-1}$ & 0.00054 \\
\hline$\delta_{\mathrm{T}}$ & Temperature coefficient for death & & 0.0693 \\
\hline$W_{\mathrm{UP}}$ & Velocity of diurnal vertical movement (upward) & $\mathrm{m}$ day $^{-1}$ & 0 \\
\hline$W_{\text {DOWN }}$ & Velocity of diurnal vertical movement (downward) & $\mathrm{m} \mathrm{day}^{-1}$ & 0 \\
\hline$[\mathrm{P}: \mathrm{C}]_{\mathrm{ZOO}}$ & Carbon-to-phosphorus ratio & & 0.02857 \\
\hline$[\mathrm{N}: \mathrm{C}]_{\mathrm{ZOO}}$ & Carbon-to-nitrogen ratio & & 0.22222 \\
\hline$[\mathrm{TOD}: \mathrm{C}]_{\mathrm{ZOO}}$ & Carbon-to-DO ratio & & 0.00351 \\
\hline \multicolumn{4}{|c|}{ Parameters of zooplankton dynamics used in the ecosystem model } \\
\hline$\alpha_{5}$ & Decomposition rate of $\mathrm{POC}$ at $0{ }^{\circ} \mathrm{C}$ & day $^{-1}$ & 0.0453 \\
\hline$\beta_{5}$ & Temperature coefficient for POC decomposition & & 0.07 \\
\hline DO0 & Half saturation constant of DO for POC decomposition & $\mathrm{mg} \mathrm{l}^{-1}$ & 1 \\
\hline$\kappa$ & DOC release ratio from $\mathrm{POC}$ decomposition & & 0.25 \\
\hline$W_{\mathrm{POC}}$ & Sinking velocity of POC & $\mathrm{m}_{\text {day }}{ }^{-1}$ & 0.432 \\
\hline$\alpha_{6}$ & Decomposition rate of $\mathrm{DOC}$ at $0{ }^{\circ} \mathrm{C}$ & day $^{-1}$ & 0.00434 \\
\hline
\end{tabular}


Table 4 (continued)

\begin{tabular}{|c|c|c|c|}
\hline Parameters & Definitions & Unit & Value \\
\hline$\beta_{6}$ & Temperature coefficient for DOC decomposition & & 0.0693 \\
\hline DO1 & Half saturation constant of DO for DOC decomposition & $\operatorname{mg~} 1^{-1}$ & 1 \\
\hline$[\mathrm{P}: \mathrm{C}]_{\mathrm{POC}}$ & Carbon-to-phosphorus ratio in POC & & 0.0005048 \\
\hline$[\mathrm{P}: \mathrm{C}]_{\mathrm{DOC}}$ & Carbon-to-phosphorus ratio in DOC & & 0.0002581 \\
\hline$[\mathrm{N}: \mathrm{C}]_{\mathrm{POC}}$ & Carbon-to-nitrogen ratio in POC & & 0.009921 \\
\hline$[\mathrm{N}: \mathrm{C}]_{\mathrm{DOC}}$ & Carbon-to-nitrogen ratio in DOC & & 0.007143 \\
\hline$\alpha_{9}$ & Release rate of phosphorus from the seabed at $28{ }^{\circ} \mathrm{C}$ & $\mathrm{mgP} \mathrm{m} \mathrm{m}^{-2} \mathrm{day}^{-1}$ & 0.0453 \\
\hline$\beta_{9}$ & $\begin{array}{l}\text { Temperature coefficient for phosphorus release from the } \\
\text { seabed }\end{array}$ & & 0.1353 \\
\hline$\gamma_{\mathrm{P}}$ & $\begin{array}{l}\text { Coefficient of ignition loss for } \mathrm{PO}_{4}-\mathrm{P} \text { release from the } \\
\text { seabed }\end{array}$ & & 0.1353 \\
\hline$T_{\mathrm{EXP}}$ & Temperature at the time of experiment & & 21.6 \\
\hline$\alpha_{10}$ & Release rate of ammonia from the seabed at $28{ }^{\circ} \mathrm{C}$ & $\mathrm{mgN} \mathrm{m}{ }^{-2}$ day $^{-1}$ & 0.3372 \\
\hline$\beta_{10}$ & $\begin{array}{l}\text { Temperature coefficient for ammonia release from the } \\
\text { seabed }\end{array}$ & & 0.0392 \\
\hline$\gamma_{\mathrm{N}}$ & $\begin{array}{l}\text { Coefficient of ignition loss for ammonia release from the } \\
\text { seabed }\end{array}$ & & 0.1353 \\
\hline$\alpha_{11}$ & Nitrification rate of $\mathrm{NH}_{4}-\mathrm{N}$ at $0{ }^{\circ} \mathrm{C}$ & day $^{-1}$ & 0.003 \\
\hline$\beta_{11}$ & Temperature coefficient for $\mathrm{NH}_{4}-\mathrm{N}$ nitrification & & 0.0693 \\
\hline $\mathrm{DO} 2$ & Half saturation constant of $\mathrm{DO}$ for $\mathrm{NH}_{4}-\mathrm{N}$ nitrification & $\mathrm{mg} 1^{-1}$ & 0.5 \\
\hline$\alpha_{12}$ & Nitrification rate of $\mathrm{NO}_{2}-\mathrm{N}$ at $0{ }^{\circ} \mathrm{C}$ & day $^{-1}$ & 0.0035 \\
\hline$\beta_{12}$ & Temperature coefficient for $\mathrm{NO}_{2}-\mathrm{N}$ nitrification & & 0.0693 \\
\hline DO3 & Half saturation constant of $\mathrm{DO}$ for $\mathrm{NO}_{2}-\mathrm{N}$ nitrification & $\mathrm{mg} 1^{-1}$ & 0.5 \\
\hline$\alpha_{13}$ & Denitrification rate of $\mathrm{NO}_{2}-\mathrm{N}$ at $0{ }^{\circ} \mathrm{C}$ & day $^{-1}$ & 0.00155 \\
\hline$\beta_{13}$ & Temperature coefficient for denitrification & & 0.0932 \\
\hline DO4 & Threshold of DO for denitrification & $\operatorname{mg} 1^{-1}$ & 2.5 \\
\hline$[\mathrm{TOD}: \mathrm{C}]_{\mathrm{POC}}$ & Carbon-to-DO ratio in $\mathrm{POC}$ & & 0.0033 \\
\hline$[\mathrm{TOD}: \mathrm{C}]_{\mathrm{DOC}}$ & Carbon-to-DO ratio in DOC & & 0.00312 \\
\hline$\alpha_{\mathrm{D}}$ & DO consumption rate of bottom sediment at $28^{\circ} \mathrm{C}$ & day $^{-1}$ & 0.00155 \\
\hline$\beta_{\mathrm{D}}$ & $\begin{array}{l}\text { Temperature coefficient for DO consumption of bottom } \\
\text { sediment }\end{array}$ & & 0.0932 \\
\hline$\beta_{\mathrm{I}}$ & Temperature coefficient for ignition loss & & 0.1794 \\
\hline DO5 & $\begin{array}{l}\text { Half saturation constant of DO for DO consumption by } \\
\text { seabed }\end{array}$ & & 0.0377 \\
\hline $\mathrm{KR}$ & Reaeration rate constant & day $^{-1}$ & 0.7 \\
\hline \multicolumn{4}{|c|}{ Other parameters used in the ecosystem model ( 3 values are those for Crassostrea Sikamea, C.gigas, C. ariakensis, respectively) } \\
\hline FRc & Constant for filtration & & $0.422,0.441,0.569$ \\
\hline Tcoef & Temperature coefficient for filtration & & $\begin{array}{l}0.0,0.773(T<25),-0.275(T \geq 25) \\
\quad-0.441\end{array}$ \\
\hline Scoef & Salinity coefficient for filtration & & $0.0,0.0,0.475$ \\
\hline cst & Constant for filtration & & $\begin{array}{l}\text { 14.727, }-0.63(T<25), 25.567(T \geq 25), \\
\quad 14.221\end{array}$ \\
\hline Ass & Coefficient of grazing restriction due to SS concentration & & 0.4451 \\
\hline Bss & Coefficient of grazing restriction due to SS concentration & & -0.0023 \\
\hline$K_{\mathrm{bsf}}$ & Half saturation constant of shell density for grazing & $\mathrm{g} \mathrm{m}^{-2}$ & 10 \\
\hline$\alpha_{\mathrm{bsf}}$ & Production rate of feces & day $^{-1}$ & 0.57 \\
\hline $\mathrm{ASSI}_{\mathrm{bsf}}$ & Assimilation rate & & 0.45 \\
\hline$\beta_{\mathrm{bsf}}$ & Excretion rate of ammonia & $\mathrm{h}^{-1}$ & $0.0012,0.1319,0.2495$ \\
\hline Q10BS3 & Temperature coefficient for ammonia excretion & & $0.1311,0.0597,0.0467$ \\
\hline$\alpha \mathrm{BS} 3 \mathrm{XM}$ & $\begin{array}{l}\text { Temperature coefficient for relationship between ammonia } \\
\text { excretion and mussel body size }\end{array}$ & & $0.0232,0.0865,0.0117$ \\
\hline
\end{tabular}


Table 4 (continued)

\begin{tabular}{|c|c|c|c|}
\hline Parameters & Definitions & Unit & Value \\
\hline$\beta B S 3 X M$ & Constant value for excretion & & $0.1738,-1.2012,0.4612$ \\
\hline $\mathrm{BS} \mathrm{XM}_{1}$ & $\begin{array}{l}\text { Temperature coefficient for relationship between DO con- } \\
\text { sumption by respiration and mussel body size }\end{array}$ & & $0.689,0.663,0.197$ \\
\hline $\mathrm{BS} \mathrm{XM}_{2}$ & $\begin{array}{l}\text { Coefficient for relationship between DO consumption by } \\
\text { respiration and mussel body size }\end{array}$ & & $-1.105,-0.755,-0.866$ \\
\hline Q10BS5 1 & Temperature coefficient for DO consumption by respiration & & $0.0,0.0,0.022$ \\
\hline $\mathrm{Q}^{10 B S 5} 5_{2}$ & Coefficient for DO consumption by respiration & & $0.047,0.032,0.035$ \\
\hline
\end{tabular}

\section{References}

Chen C, Liu H, Beardsley RC (2003) An unstructured grid, finitevolume, three-dimensional, primitive equations ocean model: application to coastal ocean and estuaries. J Atmos Ocean Technol 20:159-186

Ciappa AC (2006) An operational comparative test of $z$-levels PGF schemes to reduce pressure gradient errors of the ocean model POM. Ocean Model 12:80-100

Davies HC (1976) A lateral boundary formulation for multi-level prediction models. Q J R Meteorol Soc 102:405-418

Fairall CW, Bradley EF, Hare JE, Grachev AA, Edson JB (2003) Bulk parameterization of air-sea fluxes: updates and verification for the COARE algorithm. J Clim 16:571-591

Galperin B, Kantha LH, Hassid S, Rosati A (1988) A quasi-equilibrium turbulent energy model for geophysical flows. J Atmos Sci 45:55-62

Hamada T, Yamamoto K, Hayami Y, Yoshino K, Ohgushi K, Yamaguchi S, Katano T, Yoshida M (2009) Numerical simulation of sediment transport in the Ariake Sea with erosion property mapping. Annu J Coast Eng JSCE 56:986-990

Hanawa K, Mitsudera H (1985) On daily average of oceanographic data. Coast Oceanogr Bull 23:79-87 (in Japanese)

Hayami Y, Fujii N (2017) Decadal-scale variation in COD and DIN dynamics in summer in the inner area of the Ariake Sea, Japan. J Oceanogr (in press)

Hayami Y, Hamada T (2015) Isahaya Bay, fresh water lake to an estuary again. Mar Pollut Bull 102:250-255

Hayami Y, Yamamoto K, Ougushi K, Hamada T, Hirakawa R, Miyasaka J, Oomori K (2006) Transportation of suspended sediment and its effects on water quality in inner Ariake Sea in summer. Annu J Coast Eng JSCE 53:956-960 (In Japanese)

Horiguchi F, Nakata K (1994) Numerical eco-hydrodynamical model application to Fukuoka Bay. J NIRE 3:31-45

Joh H (1989) Oxygen-deficient water in Osaka Bay. Bull Coast Oceanogr 26:87-98 (in Japanese with English abstract)

Jørgensen BB (1996) Case study-Aarhus Bay. In: Jørgensen BB, Richardson K (eds) Eutrophication in coastal marine ecosystems, 1 st edn. Coastal and estuarine studies, vol 52. American Geophysical Union, New York, pp 137-154

Kobayashi Y (1994) Movement of the anoxic water mass in the coastal area of Tokyo Bay. Bull Kanagawa Prefect Fish Res Inst 15:1-5 (in Japanese with English abstract)

Kuno M (1996) Seasonal variation of sea conditions in Ise Bay. Bull Fish Res Inst Mie 6:27-46 (in Japanese with English abstract)

Linden PF, Simpson JE (1988) Modulated mixing and frontgenesis in shallow sea and estuaries. Cont Shelf Res 8:1107-1127

Manda A, Matsuoka K (2006) Changes in tidal currents in the Ariake sound due to reclamation. Estuar Coasts 29:645-652
Matsukawa Y, Sasaki K, Hanyu Y (2014) Causality between hypoxia of Ariake Sea environment and reclamation in Isahaya Bay, Japan. Oceanogr Jpn 23:87-110 (In Japanese with English abstract)

Matsumoto K, Takanezawa T, Ooe M (2000) Ocean tide models developed by assimilating TOPEX/POSEIDON altimeter data into hydrodynamical model: a global model and a regional model around Japan. J Oceanogr 56:567-581

Mellor GL, Yamada T (1982) Development of a turbulence closure model for geophysical fluid problem. Rev Geophys Space Phys 20:851-875

Ministry of the Environment (2002) Report of supplemental survey on water quality in Ariake Sea, p 292 (Japanese)

Ministry of the Environment (2006) Report of the commission for the assessment of comprehensive research on Ariake Sea and Yatsushiro Sea, p 85 (Japanese)

Miyazawa Y, Zhang R, Guo X, Tamura H, Ambe D, Lee JS, Okuno A, Yoshinari H, Setou T, Komatsu K (2009) Water mass variability in the western North Pacific detected in a 15-year eddy resolving ocean reanalysis. J Oceanogr 65:737-756

Nagao K, Takeuchi K, Hata K, Horita K, Kimura N (2010) Sensitivity analysis for dominant factors of hypoxia caused by long term environmental changes in Ariake Sea. J JSCE Ser B2 Coast Eng 66:1136-1140 (in Japanese with English abstract)

Nakata K (1993) Ecosystem model; its formulation and estimation method for unknown rate parameters. J Adv Mar Technol Conf 8:99-138 (in Japanese with English abstract)

Officer CB, Bigs RB, Taft JL, Cronin LE, Tyler MA, Boynton WR (1984) Chesapeake Bay anoxia: origin, development and significance. Science 223:22-27

Pietrzak JD, Jakobson JB, Burchard H, Vested HJ, Petersen O (2002) A three-dimensional hydrostatic model for coastal and ocean modelling using a generalised topography following co-ordinate system. Ocean Model 4:173-205

Rabelais NN, Turner RE (2001) Hypoxia in the northern Gulf of Mexico: description, causes and change. In: Rabelais NN, Turner $\mathrm{RE}$ (eds) Coastal hypoxia: consequences for living resources and ecosystems, vol 58. American Geophysical Union, Coastal and Estuarine Studies, Washington, D.C., pp 1-36

Sasaki K, Hodoki Y, Murakami T (2003) Increments of COD, total nitrogen and total phosphorus discharge to Isahaya Bay since the embankment in 1997. Oceanogr Jpn 12:573-591 (in Japanese with English abstract)

Seikai National Fisheries Research Institute, Saga University (2012) A plan to restore the ecosystem of Ariake Bay. Investigations of Ecological Functions of Oyster Reefs, Japan, p 186

Seikai National Fisheries Research Institute, Saga University (2013) A plan to restore the ecosystem of Ariake Bay. Investigations of Ecological Functions of Oyster Reefs, Japan, p 181

Simpson JH, Allen CM, Morris NCG (1978) Fronts on the continental shelf. J Geophys Res 83:4607-4614 
Simpson JH, Brown J, Matthews J, Allen G (1990) Tidal straining, density currents, and stirring in the control of estuarine stratification. Estuaries 13(2):125-132

Smagorinsky J (1963) General circulation experiments with the primitive equations, I. The basic experiment. Mon Weather Rev 91:99-164

Suzuki T (2001) Oxygen-deficient waters along the Japanese coast and their effects upon the estuarine ecosystem. J Environ Qual 30:291-302

Suzuki T, Matsukawa Y (1987) Hydrography and budget of dissolved total nitrogen and dissolved oxygen in the stratified season in Mikawa Bay, Japan. J Oceanogr Soc Jpn 43:37-48

Tai A, Yano S (2008) Variation of M2 tidal amplification in the Ariake Sea based on outer sea tide and influence of the Isahaya Sea-Dyke. Oceanogr Jpn 17:205-211 (in Japanese with English abstract)

Tokunaga T, Isono M, Matsunaga N (2009) Oxygen consumption process during the resuspension of muddy sediment from Ariake Bay-a laboratory assessment. J JSCE 65:269-276 (in Japanese with English abstract)
Unoki S (2002) Temporal change of tides and currents in Ariake Bay, related to the reclamation in Isahaya Bay. Umi Sora (Sea and Sky) 78:19-30 (in Japanese with English abstract)

Welsh BL, Eller FC (1991) Mechanisms controlling summertime oxygen depletion in western Long Island Sound. Estuaries $14: 265-278$

Yamaguchi S, Kyozuka Y (2006) Generation mechanism of hypoxia in Isahaya Bay. Oceanogr Jpn 15:37-51 (in Japanese with English abstract)

Yamaguchi S, Hayami Y, Kimoto K (2015) Inhibition effect of oyster reef on occurrence of hypoxia in Ariake Sea. Bull Coast Oceanogr 53:25-38 (in Japanese with English abstract)

Yoshino K, Hamada T, Yamamoto K, Hayami Y, Yamaguchi S, Ohgushi K (2010) Effects of hypoxia and organic enrichment on estuarine macrofauna in the inner part of Ariake Bay. Hydrobiologia 65:23-38 